\title{
ARKADIUSZ STANISZEWSKI \\ Miejsce katolicyzmu polskiego w nowych strukturach społecznych, kulturowych i gospodarczych Unii Europejskiej. Strategia dialogu i ekumenizmu
}

\section{Europa - religijny i społeczno-kulturowy tygiel}

$\mathrm{Na}$ europejskie dziedzictwo kulturowe i cywilizacyjne skladają się dwie wielkie tradycje: Wschodu i Zachodu. W pewnym uproszczeniu można powiedzieć, że podwaliny intelektualne kultura wschodnia czerpie z idei Platona i św. Jana, natomiast zachodnia sięga do Arystotelesa i św. Pawła. Wschód to duch, metafizyka i prawosławie, Zachód - rozum, racjonalizm, katolicy i protestanci. Tak wielkie bogactwo chwały, zebrane $z$ różnych form wielkiej tradycji Kościoła, mogłoby nam dopomóc do tego, aby Kościół zaczał na nowo oddychać w pełni »obydwoma płucami«: jest to dzisiaj bardziej konieczne nizz kiedykolwiek. Stałoby się to wielkq pomoca w rozwoju dialogu prowadzonego pomiędzy Kościołem katolickim i innymi Kościołami oraz Wspólnotami kościelnymi Zachodu - pisał Jan Paweł II w Encyklice Redemptoris Mater z 1987 r. Metafora papieska odnosi się przede wszystkim do działań ekumenicznych, ponieważ coraz częściej problem ten pojawia się w dyskusjach dotyczących kształtu religijnego przyszłej Europy. Nie może być mowy o autentycznym zjednoczeniu kontynentu, jeśli we wspólnej Europie nie znajdzie się miejsce dla obu wyżej wymienionych tradycji, które mimo świadomości o wspólnych korzeniach ewangelizacyjnych i historycznych nadal sa podzielone. Istnieją bowiem obawy, że po zlikwidowaniu $\dot{z} e-$ laznej kurtyny wykreują się nowe podziały, na kraje czerpiące $\mathrm{z}$ bogactwa doczesnego i kulturowego Unii Europejskiej, kraje katolickie i protestanckie (wyjatek pod względem wyznaniowym stanowi Grecja) oraz kraje prawosławnego wschodu. Wyznawców prawosławia najbardziej irytuje teza, że Europa kończy się tam, gdzie zaczyna się prawosławie - mówi profesor Viorel Ionita, prawosławny teo$\log$ z Bukaresztu. Dominują bowiem wartościujące opinie, że tylko to, co wy- 
plywa z dorobku kultury zachodniej, jest tożsame z tym, co europejskie. Pomiędzy krajami Europy zrzeszonej w Unii i poza nią z pewnością stanie bariera ekonomiczna. Zarysuje się również izolacja przestrzenna, polskie MSZ wprowadziło już wizy dla obywateli zza naszej wschodniej granicy, co jest zgodne z wymogami stawianymi przez Unię Europejską. Służby Celne i Wojska Ochrony Pogranicza są przerzucane na wschód, by uszczelnić nową wschodnią granicę Unii, a w środkach masowego przekazu do lask wraca określenie przedmurze chrześcijaństwa i wschodnia rubież Europy. Pojawiają się więc początki polityki izolacji, sprzeczne z ideami integracyjnymi postulowanymi po upadku komunizmu. $W_{y-}$ darzenia w Polsce sprzed dziesięciu lat stworzyly historycznq szansę, by kontynent europejski, porzuciwszy ostatecznie ideologiczne bariery, odnalazł droge $k u$ jedności. Mówiłem o tym wielokrotnie, rozwijajqc metaforę »dwóch płuc«, którymi winna oddychać Europa, zespalajqc w sobie tradycje Wschodu i Zachodu. Zamiast jednak oczekiwanej wspólnoty ducha dostrzegamy nowe podziały i konflikty. Sytuacja ta niesie dla polityków, dla ludzi nauki i kultury i dla wszystkich chrześcijan pilnq potrzebe nowych działań shuzqcych integracji Europy - mówil Jan Paweł II w czerwcu 1999 r., podczas wizyty w polskim parlamencie. Papież nie podaje gotowej recepty na połączenie obu kultur i stworzenie jednolitej duchowo Europy, mówi natomiast o wyzwaniu, jakie przypadło w związu z tym chrześcijanom.

Chrześcijanie świeccy, jako obywatele i politycy, powinni także wspierać proces rozszerzania Unii przez wzgląd na wzbogacenie kultury w sposób dyfuzyjny. W kolejce do czlonkostwa w Unii stoja prawosławne kraje, takie jak Rumunia i Bułgaria. Ważne jest, aby przystqpienie dziesięciu nowych państw członkowskich nie prowadziło do nowych podziałów w Europie. Wielkie wysiłki na rzecz przygotowań do członkostwa w Unii Europejskiej podjeły już Bułgaria $i$ Rumunia, choć nie sq one jeszcze gotowe do zamknięcia rokowań $w$ sprawie przystqpienia. Zachęcamy je do kontynuowania tych wysitków i z zadowoleniem witamy zaangażowanie Unii na rzecz zwiększania pomocy, aby kraje te osiqgnęfy cel, jaki same sobie postawily, a mianowicie przystapienie do UE w 2007 r. stwierdzono w deklaracji Komisji Episkopatów Wspólnoty Europejskiej (COMECE) odnośnie przystapienia nowych państw do UE. Deklaracja Komisji Episkopatów Wspólnoty Europejskiej pt. Nadzieja, zaufanie, solidarność została ogłoszona przed szczytem w Kopenhadze. Pada tutaj wątpliwość, czy owocna będzie ta współpracować oraz dialog pomiędzy religiami, jeśli nie zna się partnera tych relacji, a przecież wiedza przeciętnego katolika czy protestanta z Europy Zachodniej na temat prawosławia jest szczątkowa. Dlatego dużą rolę powinny, na tym etapie dialogu, odegrać chrześcijańskie media i ośrodki naukowe. Można by też przybliżyć wiernym tradycję i teologię Kościołów chrześcijańskich. Warto więc wykorzystać takie inicjatywy jak Tydzień Modlitw o Jedność Chrześci- 
jan, obchodzony każdego roku w styczniu. Polsce jako krajowi pogranicza religijno-kulturowego może przypaść odpowiedzialna rola pośrednika między wschodem i zachodem, metafizyka, duchowościa, a pragmatyzmem. Rola ta nie będzie podejmowana po raz pierwszy, gdyby cofnać się kilka wieków wstecz.

Kościól pamiętając o tym, że na chrześcijańską tożsamość Europy składa się tradycja i Wschodu, i Zachodu w ramach ekumenizmu podkreśla, że to, co podobne, winno Kościoły łączyć, natomiast to, co jest różne, ma je wzbogacać. Chrześcijańskie korzenie Europy to nie tylko św. Benedykt i św. Wojciech, ale też święci Cyryl i Metody. Tendencje zjednoczeniowe i ekumeniczne bazujące na wspólnych korzeniach są wyraźne, zarówno wśród przedstawicieli katolickich środowisk intelektualnych w Polsce jak i w krajach obecnej Unii. Kościoły powinny być pomostem między Wschodem a Zachodem - mówił w 2001 r. Wolfgang Thierse, przewodniczacy Bundestagu i czołowy polityk niemieckiej socjaldemokracji, podczas Kongresu „Renovabis - Akcji Solidarności Katolików Niemieckich z Mieszkańcami Europy Środkowej i Wschodniej". Wielu przedstawicieli Kościoła, jak i osób świeckich zadaje sobie pytanie w jaki sposób chrześcijanie maja w praktyce budować te pomosty? Wysilek ten komplikuje fakt, że Kościoły Wschodu i Zachodu nadal pozostaja podzielone. Stąd właśnie ruch ekumeniczny poprzez dążenie do zjednoczenia chrześcijaństwa jest istotnym elementem budowy zjednoczonego kontynentu w sferze spolecznej i moralnej. Biorąc pod uwage świecki charakter Unii, Kościoły tylko współpracując ze sobą będą liczącym się głosem na europejskiej arenie politycznej i społecznej. Poza tym Kościól jest wspólnotą osób świeckich i duchownych. Dlatego też współpraca Kościołów, tj. świeckich i duchownych członków wspólnot winna doprowadzić do zbliżenia społeczeństw, co stanowi fundamentalny filar integracji europejskiej.

Kamieniem milowym na drodze ekumenicznego dialogu i zjednoczenia Kościołów Europy Wschodniej, a także Zachodniej jest prowadzona od ćwierćwiecza działalność Jana Pawła II. Oprócz niezliczonych wypowiedzi, gestów, encyklik czy dokumentów świadczących o jego zaangażowaniu na rzecz jedności chrześcijan często mówi się o papieskich pielgrzymkach i spotkaniach z przedstawicielami Kościołów wschodnich. Można tutaj wspomnieć podróż do Rumunii w maju 1999 r. (kraju o przewadze wyznawców prawosławia), na Ukrainę w czerwcu 2001 r., czy do Bułgarii w maju 2002 r. W październiku 2002 r. w Watykanie gościł zwierzchnik Rumuńskiego Kościoła Prawosławnego patriarcha Teoktyst. Podczas spotkania patriarcha wyraził obawę o zauważalne procesy zdechrystianizowana Europy, która stanowiąc coraz silniejszą jedność gospodarcza, legislacyjna, cywilizacyjną i kulturowa, nie dba o poparcie Kościołów chrześcijańskich dla procesów unifikacyjnych kontynentu. Przedstawiciel Ko- 
ścioła prawosławnego podkreślil, że tylko współpracujące ze sobą Kościoły będa w stanie wywrzeć jakikolwiek znaczący wplyw na integrację europejska.

Dialog między wyznaniami chrześcijańskim, który szybko rozwija się od Soboru Watykańskiego II, przeżywa jednak dobre i zle chwile. Kościól katolicki utrzymuje dobre stosunki np. z prawosławnym patriarchatem w Konstantynopolu, któremu przewodniczy Bartłomiej I. Natomiast stosunki z Patriarchatem Moskiewskim są bardzo napięte; zwłaszcza po tym, jak w 2002 r. Stolica Apostolska podniosła do rangi diecezji cztery administratury apostolskie w Rosji. Następstwem było m.in. utrudnianie katolickim kapłanom wykonywania swojej posługi. Tamtejsza Cerkiew zarzuca katolikom uprawianie tzw. prozelityzmu, czyli agresywnej akcji misyjnej na terenach tradycyjnie prawosławnych ${ }^{1}$.

Bardzo ważnym forum kontaktów prawosławno-protestancko-anglikańskich jest Światowa Rada Kościołów, założona w 1948 r. Dziś należą do niej 342 wspólnoty i stowarzyszenia chrześcijańskie z kilkudziesięciu krajów, liczące ponad $400 \mathrm{mln}$ wiernych. Zgromadzenie Ogólne Rady jest organem zarządzanym przez Arama I, ormiańskiego patriarchę Cylicji oraz dr Konrada Raisera, ewangelika z Niemiec. Rada spotyka się raz na kilka lat. Komitet Naczelny ŚRK, zlożony ze 160 przedstawicieli różnych wyznań sprawuje ciągłą kontrolę nad statutową działalnością. Z uwagi na mnogość przedstawicieli różnych wyznań także w Światowej Radzie Kościołów dochodzi do sporów, np. dotyczących nadmiernego liberalizmu w decyzjach Rady (m.in. zgody na kaplaństwo kobiet, wprowadzanie do liturgii i tłumaczeń Biblii tzw. języka inkluzywnego, tj. ukazywania Boga jako istoty o cechach kobiecych i męskich zarazem, np. dokonywano zmian w wersach Modlitwy Pańskiej: Ojcze-Matko nasza). Kościół katolicki ma w ŚRK status obserwatora.

\section{Kościół w poszukiwaniu jedności}

Bardzo ważnym wyzwaniem dzisiejszych czasów, czasów stojących pod znakiem zjednoczenia jest kwestia jedności chrześcijan. Można by zacytować swoisty testamentem dla Kościoła, którym jest modlitwa Jezusa Chrystusa: Oby się tak zespolili w jedno, aby świat poznał, żeś Ty Mnie posłał i że Ty ich umiłowałeś, tak jak Mnie umiłowałeś (J 17, 23). Zadaniem chrześcijan jest prowadzić działanie w kierunku tworzenia jednego Kościoła, mającego możliwości reali-

${ }^{1}$ Ostatnio Kościół katolicki znalazł się na pierwszym miejscu wśród organizacji zagrażających bezpieczeństwu państwa w Raporcie o ekstremizmie religijnym w Rosji przygotowanym przez przedstawicieli administracji prezydenta, rządu federalnego i służb specjalnych. Kontaktów Kościoła katolickiego z prawosławnym nie ułatwiają także wewnętrzne podziały w ramach tej wspólnoty, np. na Ukrainie działaja trzy nawzajem nie uznające się Cerkwie - Autokefaliczna, Patriarchat Kijowski i Patriarchat Moskiewski. 
zowania swojego posłannictwa w nowej, pojmowanej globalnie rzeczywistości. Sformułowano apele, m.in. wychodzące z ust Jacques'a Delors'a, ówczesnego przewodniczącego Komisji Europejskiej, iż trzeba dać Europie duszę, ponieważ konstrukcja prawno-gospodarcza nie może stanowić prawdziwej Europy. Nasuwa się tutaj porównanie do Goliata, glinianego kolosa, bezsilnego, gdyby pozbawić go kreatywnego/magicznego słowa na zwitku pergaminu (duszy).

Złożona sytuacja Kościoła w Europie, stojącego przed długą drogą do jedności jest bardzo skomplikowana. Tego typu wysiłki są podejmowane, choć może nadal w zbyt małej skali. Ale także trzeba zwrócić uwagę, że często oczekujemy szybkich, spektakularnych sukcesów, podczas gdy droga przed Kościolem jest długa i wyboista. Aczkolwiek w zakresie oficjalnego dialogu ekumenicznego dokonano już bardzo wiele, zwłaszcza od czasu Soboru Watykańskiego II. Bardzo ważnym etapem na tej drodze jest Wspólna Deklaracja w sprawie nauki o usprawiedliwieniu, podpisana 31 października 1999 r. w Augsburgu przez przedstawicieli Kościoła rzymskokatolickiego oraz luterańskiego. Jest to sygnał, że po niemal pięciu stuleciach rozpoczęła się drogę odwrotu od tendencji rozłamowych, zapoczątkowanych w XVI w. Podobnie bardzo ważną sprawą są wszelkie deklaracje o wzajemnym uznawaniu sakramentu chrztu - dokument taki zostal podpisany także w Polsce ${ }^{2}$.

Sprawa jedności Kościoła to nie tylko zagadnienia ekumeniczne - także wewnątrz Kościoła katolickiego powinniśmy o tę jedność bardzo się starać. Nawet $\mathrm{w}$ naszym lokalnym otoczeniu niejednokrotnie napotykamy trudności, na przykład w relacjach między wspólnotami łacińskimi, a greckokatolickimi. Trzeba wiele cierpliwości i obustronnej dobrej woli, aby je przezwyciężyć; chyba trzeba też przezwyciężyć falszywe tendencje do lączenia spraw kościelnych ze sprawami stosunków między narodami. Religijny nacjonalizm jest zawsze tragicznym nieporozumieniem - św. Paweł już dawno temu pisal, iż nie ma już Żyda ani poganina, nie ma już niewolnika ani człowieka wolnego, nie ma już mężczyzny ani kobiety, wszyscy bowiem jesteście kimś jednym w Chrystusie Jezusie (Ga 3, 28; por. Kol 3, 11). Dlatego tak ważne jest właściwe ustawienie relacji między wiarą chrześcijańską a patriotyzmem, choć narody europejskie mają z tym poważne trudności. Dialog, jaki toczy się obecnie w społeczeństwie i Kościele odnośnie roli Polski w strukturach UE, ukazuje, jak trudno przełamać zakorzenione stereotypy myślenia.

\footnotetext{
${ }^{2}$ Por. M. P i én k o w s k i: Jak warto patrzeć na Kościót? „Pastores”. R. 2003 nr 18 (1) s. 7 19.
} 


\section{Społeczeństwo polskie i Kościół katolicki wobec nowych trendów przemian społecznych i kulturowych}

Dla Polaków jeszcze do niedawna słowo globalizacja kojarzyło się $z$ happeningami ulicznymi w Toronto, Davos, Durbanie, Pradze, itd. Młodzi ludzie roztańczeni, ze śpiewem na ustach ścierali się z policją, demolowali znienawidzone restauracje McDonald's, palili samochody. Typowe obrazy z serwisów informacyjnych, do których „przyzwyczaja się" nas od wielu już lat, obrazy zewnętrzne, nie dotyczące na pozór Polski. Obecnie przemiany globalne odciskają wyraźne piętno na strukturze spolecznej w Polsce, ponieważ nie wystarczy już rola obserwatora, musimy jako spoleczeństwo dokonać wyborów, zajać stanowisko, czasem sprzeciwić się. Takim zagadnieniem pełnym pytań i nie udzielonych jeszcze odpowiedzi jest dalsza rola religii katolickiej w Polsce po jej wejściu do UE. Padają również pytania o przyszlą rolę katolicyzmu polskiego w Unii. Czy polskim katolikom przypadnie rola, którą ponad 1000 lat temu odegrał św. Wojciech w Polsce?

Często na pytanie, czy wejście do UE oznacza upadek wartości moralnych eksperci i autorytety odpowiadaja, że nie potrzeba wchodzić do Unii, by społeczeństwo uległo degradacji, wręcz autodestrukcji moralnej. Prawdą jest, że jednak wciąż mamy zapisy prawne, różne od unijnych w zakresie rozwodów, aborcji, pornografii, reklam używek, eutanazji, antykoncepcji, preferencji legislacyjnych co do nowych "modeli rodziny”. Prawodawstwo ułatwia działanie organizacjom religijnym i zapewnia w miarę możliwości sprzyjające warunki ochrony przed sektami. Wejście do Unii w wielu przypadkach wymusi dostosowanie prawa natychmiast, bądź w najbliższej przyszłości do standardów unijnych.

W lipcu 2002 r. parlament europejski przyją Raport w sprawie zdrowia seksualnego i reprodukcyjnego. Poprzez ten dokument dopuszcza się aborcję i antykoncepcję. Charakterystyczne, że raport spotkał się z krytyką nie dlatego, że jest niemoralny, ale ponieważ nie sprzyja euroentuzjastom. O legalizacji aborcji w Szwajcarii w czerwcu 2002 r. zadecydowało referendum - pomysł głosowania w sprawie życia ludzkiego chcą także przeforsować członkowie Unii. Z kolei Trybunał Konstytucyjny Niemiec potwierdził 16.07.2002 r., że homoseksualiści moga zawierać małżeństwa, uznając to za zgodne $z$ prawem konstytucyjnym. Szwecja w czerwcu 2002 r. głosowala za dopuszczeniem adopcji w parach homoseksualnych. Holendrzy dopuszczają prawne zawieranie małżeństw homoseksualnych od kwietnia 2002 r., rozszerzając uprawnienia takich małżeństw do możliwości adopcji dzieci. Należy przypuszczać, że „dyskryminujące”, w rozumieniu prawodawstwa unijnego ustawy w innych krajach członkowskich, takich jak choćby Polska mogą zostać zaskarżone przez obywateli Polski do instytucji unijnych w Strasburgu. 
Każdy obywatel Unii Europejskiej ma narzędzie prawne do walki z nierównościami prawnymi na terenie całej Unii, może to wykorzystać do podważania, bądź zmiany standardów prawnych o charakterze lokalnym, narodowym, np. polskim. Może to stanowić pewne zagrożenie dla suwerennych decyzji Polski, ponieważ Unia może wywierać na poszczególne państwa czlonkowskie nacisk, np. ekonomiczny, jeśli zostaną naruszone prawa czlowieka i obywatela ( $w$ świetle legislacyjnych przepisów Unii Europejskiej).

Polska zostanie de facto włączona w struktury Unii Europejskiej już w maju 2004 r. Ta chwila prowokuje do stawiania wielu pytań dotyczących przyszłości Polski i Polaków w tym europejskim tyglu kulturowym. Polacy próbują odpowiedzieć sobie na pytanie, czy ów tygiel nie homogenizuje naszej narodowej tożsamości, idei i wartości wypływających z religii, a narażonych na przeciwwagę atrakcyjnego liberalizmu unijnego opartego w głównej mierze o świeckie idee. Wielkie znaczenie mają tutaj postulaty i diagnozy wysuwane przez przedstawicieli środowisk opiniotwórczych. Katolicka Agencja Informacyjna zamieszcza je na swojej witrynie internetowej. Jedna $z$ takich diagnoz dotyczy problematyki zachowania i pielęgnowania tożsamości narodowej i religijnej w warunkach Unii Europejskiej.

Na to pytanie odpowiadają: socjolog prof. Edmund Wnuk-Lipiński, prymas Belgii kard. Godfried Danneels, metropolita poznański abp Stanisław Gądecki oraz metropolita gnieźnieński abp Henryk Muszyński.

Abp Stanisław Gądecki, metropolita poznański: Będziemy sobq. Po wejściu do Unii Europejskiej Włosi pozostali Wlochami, Francuzi - Francuzami, a Hiszpanie - Hiszpanami. To prawda, że każdy z tych krajów odczuwa presje praw unijnych i na co dzien doświadcza trudności z ich realizacja, jednak żaden z tych krajów nie utracil swojej duszy. Polska jest krajem mocnym, dużym, majacym swojq dlugq historię i swojq własnq tożsamość, która nie może po prostu wyparować. Chyba, że nie miałby żadnego szacunku do siebie, $i$ że dotad żyje życiem pozornym i nieprawdziwym.

Prof. Edmund Wnuk-Lipiński, socjolog. Jeżeli Polacy będq się czuli Polakami, to będq się czuli tak bardziej w Unii niż poza niq. Kiedy Polacy sq między sobq, tożsamość narodowa nie ma wyróżnika, bowiem tożsamości ujawniajq się w różnych kontekstach społecznych. Kiedy spotyka się Belg i Niemiec w buszu afrykańskim, to nie ujawniajq się ich tożsamości narodowe w pierwszej mierze, tylko europejska. To dwóch Europejczyków spotkało się w afrykańskim buszu. Kiedy ${ }_{w}$ Unii Europejskiej spotyka się Duńczyk z Francuzem, czy Niemiec z Anglikiem, to oni nie myślq o sobie, że sq Europejczykami, bo wiedzq, że sq Duńczykami, Francuzami, Niemcami czy Anglikami. Podstawq tworzenia tożsamości 
europejskiej może być jeden $z$ ważniejszych elementów kulturowych, tj. religia wraz z zawartym w niej przesłaniem moralnym i etycznym. Próby unifikacji krajów Europy ze względu na wiarę miały już miejsce w przeszłości $i^{3}$, jednak nigdy jeszcze nie mialy tak dobrego podłoża społecznego, militarnego i gospodarczego. Dotychczasowe obserwacje wskazujq, że poprzez obcowanie z innymi narodowościami $w$ Unii Europejskiej nie tylko nie zanika tożsamość narodowa, ale co więcej utwierdza się, rośnie, dlatego że jest ciqgle wystawiana na inne tożsamości narodowe. Nawet gdyby Polacy chcieli zapomnieć o swojej tożsamości narodowej, to inni im o niej przypomnq, bo oprócz poczucia własnej tożsamości jest tożsamość nabywana przez tzw. stygmatyzację, czyli postrzeganie innych.

Abp Henryk Muszyński, metropolita gnieźnieński mówi, że obawy [przed Uniq Europejskq] wynikajq bez wqttpienia z lęku, że religijność i wiara Polaków na skutek laicyzujacych wpływów zostanie znacznie osłabiona. Nie ulega wqtpliwości, że wejście Polski do Unii jest poważnym wyzwaniem dla wiary Polaków. Osobiście nie podzielam tych obaw. Stwierdzenie, że nie pójdziemy do Europy, gdyz jest ona bezbożna, jest z gruntu falszywe. Fakt, że Europa jest bezbożna wskazuje na potrzebę ewangelizacji. Jako chrześcijanie i wierni Kościoła musimy sobie uświadomić, że jesteśmy posłani do wszystkich. Istota problemu tkwi w tym, czy ten chrześcıjański wymiar, o którym tyle mówimy, będziemy potrafili $w$ sposób skuteczny zaprezentować na zewnqtrz. Czy nasz polski katolicyzm potrafimy przełożyć na kategorie bardziej powszechne, możliwe do przyjęcia dla innych społeczeństw. Jeżeli nasza wiara będzie dorastała do miary wyzwań, możemy z tego procesu wyjść wzmocnieni. Wymaga to jednak ustawicznego wysitku nad pogłębieniem jakości naszej wiary (KAI) ${ }^{4}$.

${ }^{3}$ Zob. D. M a t t h e w: Wielkie kultury świata. Europa średniowiecza. Warszawa 1996 s. $36-$ $108 ; 182-206 ;$ T. K o r z o n: Kurs historyi wieków średnich. Warszawa 1872 s.63-73; 201-242; $277-285$.

${ }^{4}$ Opinie ekspertów i przedstawicieli środowisk opiniotwórczych cyt za: e.kai.pl magazyn internetowy katolickiej agencji informacyjnej (http://europa.e.kai.pl/).

** Papiez akceptuje Unię ale pod określonymi warunkami. Przede wszystkim pod warunkiem uznania tożsamości narodów, szacunku do wartości chrześcijańskich i ogólnoludzkich (...) sq dla mnie dwa pryncypia, do których biskupi musza się odnieść zabezpieczenie tożsamości kulturowej $i$ szanowanie praw Bożych, które sq uniwersalne. Jeśli dojde do rozeznania, że jest to zagrożone, bede glosował na "nie" (....) Historia uczy, że tam gdzie w życiu publicznym usuneto sie Boga. tam gdzie ginie prawdziwa religia, nie pojawia sie pustka, ale wchodzi antyreligia, przesqd, uprzedzenie. Ginie szeroki humanizm religıjny, jawi sie dehumanizacja. Liberalizm bez religii skutecznie przygotowuje wejście totalitaryzmu (ks. abp J. M i c h a li k - za tyg. „Źródło”).

** Jeżeli Polska wejdzie do Unii, przejdzie przez najgłębsza przemiane strukturalna $w$ swej historii, a w końcu zniknie jako niepodlegle państwo (prof. N. F r a g e 11 i).

** Zawierzcie mojej metodziel Ja wam dostarcze wschodnie landy w taki sposób, że ich dzisiejsi administratorzy, Polacy, będq nam jeszcze wdzięczni za to, że zostali wreszcie Europejczykami (G. S c h r o e d e r). 


\section{Polak - obywatel zjednoczonej Europy. Człowiek pogranicza kulturowego}

Religia jest niezbędnym warunkiem istnienia wlaściwie zintegrowanego społeczeństwa. W sytuacjach społecznych zachowania emocjonalne i alogiczne cechuja funkcjonowanie "mas”, prowadzą bardzo często do patologii społecznych. Religia, wraz z jej zasadami i normami moralnymi stanowi naturalną $i$ niepodważalną zaporę przed tego typu dysfunkcjami spolecznymi, mając do dyspozycji m.in. sankcje negatywne i pozytywne. Konfucjusz potwierdzal integracyjną rolę religii mówiąc, ze obrzędy religijne jednoczą ludzi w określoną zbiorowość oraz stanowiq zapore przed ekscesami do których ludzie sq nawykli ${ }^{5}$. Może to być wskazówką przy otwartym problemie wciagania katolickiego kraju,

** To, do czego niektórzy tak bardzo się spiesza, to nie jest Europa. Tę prawdziwa Europe Polska może wskrzesić, jeśli będzie soba i jeśli przyjmie profetyczne nauczanie Jana Pawła II. Nie pozwólmy, by nas jeszcze raz sprzedano na „wolnym rynku” Europy (ks. prof. J. B a j d a - Instytut Edukacji Narodowej).

** Demokracja albo bęzie chrześcıjańska, albo jej nie będzie. Demokracja antychrześcijańska jest karykatura, która skończy się albo tyraniq, albo anarchiq. (R. S c h u m a n n, ojciec UE).

** Pruski kanclerz B e th m a n n H o 11 w e g, 9 września 1914 r.: Należy osiagnać ustanowienie środkowoeuropejskiego zwiqzku gospodarczego drogq wspólnych układów celnych, obejmujacych Francje, Belgie, Holandie, Danie, Austro-Węgry, Polskę, oraz ewentualnie także Włochy, Szwecję i Norwegię. Zwiazek ten, wprawdzie bez wspólnej konstytucyjnej nadbudowy i przy zachowaniu zewnętrznej równości swoich czlonków, ale faktycznie pod niemieckim kierownictwem, bedzie musiat utrwalić panowanie gospodarcze (wirtschafliche Vorherrschaft) Niemiec nad Środkowq Europa (F. F i s c h e r 1959, Deutsche Kriegesziele, Revolutionierung und Separatfrieden im Osten 1914-1918. „Historische Zeitschrift”. Monachium, 188; 249-310; za „Opoka w Kraju” nr 44).

** Opłaty, które Niemcy muszq uiszczać za każdy kraj przystępujacy do Unii, finansuja się łatwo poprzez ogromne nadwyzki handlowe, które wygospodarowuje się $z$ handlu z tymi krajami. $Z$ ekonomicznego punktu widzenia nie powstaja dla Niemiec przez to żadne dodatkowe koszty. Niemiecki wklad $w$ rozszerzenie wynosi rocznie nieco ponad jeden miliard euro. Taniej Niemcy nie moga kupić stabilizacji na swojej granicy wschodniej (G. V e r h e u g e n 28.02 .2002 w „Wirtschaftswoche").

** Wzrośnie bieda i bezrobocie, rolnictwo nie wytrzyma konkurencji, ziemie kupiq bogaci, będzie kultura telewizyjna - bp J. Z a w i t k o w s k i („Rzeczpospolita” 12.II.02).

** Wobec takiej ideologii nie można być naiwnym. Polska i Kościót polski nie moga wchodzić na ślepo do wspólnoty bezbożnej i nieprawej, do ideologii typu rewolucji francuskiej lub bolszewickiej (ks. Czesław S. B a r t n i k).

** Pragnieniem moim (...) jest to, by Europa suwerenna $i$ wyposażona $W$ wolne instytucje rozszerzyla się kiedyś aż do granic, jakie wyznacza jej geografia, a bardziej jeszcze historia. Jakże mialbym tego nie pragnqć, skoro inspirowana wiara chrześcıjańskq kultura tak głeboko naznaczyfa dzieje wszystkich ludów naszej Europy, ludow greckich i lacińskich, germańskich i słowiańskich (Jan Paweł II - przemówienie w parlamencie europejskim, 11.10.1998).

Wypowiedzi te modeluja dwie skrajnie różne opinie na temat Unii, a także roli, jaką odegra w przemianach społecznych i kulturowych społeczeństwa polskiego.

${ }^{5}$ Zob. J.M. Y i n g e r: Funkcjonalne i konfliktowe modele społeczeństwa. W: Socjologia religii. Antologia tekstów. Wybór i oprac. W. P i w o w a r s k i. Kraków 1998 s. 75 i nn. 
jakim bezsprzecznie jest Polska w struktury unijne. Polska wniesie duży ladunek religijności, polączony $\mathrm{z}$ patriotyzmem. Integracyjną rolę religii podkreślano, gdy Polska byla rządzona przez komunistów, a Kościól katolicki konsolidowal środowiska opozycyjne. Kościól także ma swoich męczenników za wiarę i wolność, choćby ks. Jerzy Popiełuszko, czy kard. Stefan Wyszyński.

Badacze zajmujący się naukami społecznymi są skłonni podtrzymywać opinię, o wspieraniu przez religię porządku spolecznego. Jednak bardzo często badacze opierając się o wartościujące przesłanki twierdza, ze mimo roli integrującej system społeczny, religia raczej trzyma w ryzach społeczeństwo. Pogląd ten zbliża nas do marksistowskiej tezy, ze religia jest opium dla ludu, a wszystkie konflikty i napięcia społeczne kontroluje się za pomocą funkcjonujących w jej obrębie wierzeń i praktyk religijnych. Przynosi to korzyści wąskiej elicie rządzącej, która stosuje swoistą technikę dziel i rzqdź, blokując jednocześnie proces zmian, którym początek mogłyby dać twórcze, reformatorskie jednostki z podporządkowanych mas. ${ }^{6}$ Są to praktyki stosowane i spotykane w zjednoczonej Europie, m.in. w Irlandii Pólnocnej, gdzie Belfast stał się krwawą areną walk pomiędzy katolikami (Irlandczykami) i protestantami (Anglikami). W byłej Jugosławii podziały etniczne pokrywają się $\mathrm{z}$ różnicami w wyznawanej religii muzułmańskiej, katolickiej i prawosławnej prowadząc do eskalacji etniczno-religijnego konfliktu ${ }^{7}$.

Yinger pisząc o zmiennych wpływających na integracyjną funkcję religii podaje nam, że religia pełni mniejszą rolę integracyjną w spoleczeństwie, którego członkowie wyznają więcej niż jedną religię, co można z całą pewnością stwierdzić biorąc pod uwagę spoleczeństwo UE. Jednak nie mówi nic na temat aktywnej dzialalności ekumenicznej, która ma na celu stworzenie zjednoczonej religii. Działania te inicjuja nie tylko środowiska katolickie, ale także innych chrześcijańskich Kościolów ${ }^{8}$.

\section{Wielowątkowość europejskiego chrześcijaństwa. Kościół z bagażem 2000 lat tradycji}

Kościół w Europie zajmuje w historii chrześcijaństwa wyjątkową pozycję. Poza Europa, tylko w zachodniej części Azji oraz lokalnie w Egipcie istnieja wspólnoty chrześcijańskie o tak długiej tradycji, przy czym tamte wspólnoty

\footnotetext{
${ }^{6}$ Zob. j.w., s. 74 .

${ }^{7}$ Zob. D. W a r s z a w s k i: Koniec Jugoslawii. „Gazeta Wyborcza” z dn. 15.03.2002 s. 10.

8 Zob. A. Leszczyński: Kościót ewangelicko-metodystyczny. "Wiedza i Życie” nr 3/1997; K. Kar s k i: Anglikanizm. „Wiedza i Życie” nr 4/1996.
} 
zostały znacząco osłabione $\mathrm{w}$ ciagu stuleci islamskiego panowania $\mathrm{w}$ sensie potencjału demograficznego oraz kulturowego. Tymczasem w Europie w ciagu stuleci Kościól nie tylko rozwijal się, ale także wzbogacał w różnorodność stylów myślenia oraz duchowości, zarówno wśród duchownych jak i świeckich. Gdy chcemy zrozumieć obecną sytuację Kościola w Europie, musimy przyjąć do wiadomości pojawianie się nowych prądów duchowych, nowych idei, nowych sposobów wyrażania wiary. Tworzy to wyjątkową wielowątkową Europę pod względem wyznaniowym.

W praktyce właśnie ta wielowq̨tkowość europejskiego chrześcijaństwa sprawia, że trudno nam ogarnąć wszystkie jej aspekty. W wyniku złożonych procesów historycznych w Kościele pojawialy się bardzo różne sposoby wyrażania wiary, różne nowe struktury organizacyjne, oraz nowe alternatywne modele duszpasterstwa. Kolejną trudność stanowią podziały wśród chrześcijan, w wyniku których różne grupy rozwijały się niezależnie, często we względnej izolacji od innych grup chrześcijańskich.

Kościól przechodzi szereg przemian, jest to proces nie do końca zaplanowany, a przynajmniej brak jest ostatecznej wizji tego procesu. Najnowsza historia Kościoła w społeczeństwie jest tego dowodem. Zupełnie inaczej toczą się losy Kościoła we Francji, Irlandii, Hiszpanii, a inaczej w Niemczech. We Francji, po kryzysie przełomu lat sześćdziesiątych i siedemdziesiątych XX stulecia, Kościół odradza się jako elitarny, poniekąd mniejszościowy, ale zdumiewająco żywotny i aktywny na polu ewangelizacji i działalności społecznej. W ciagu kilku ostatnich lat powstało tam wiele nowych form życia zakonnego i wspólnot dla świeckich, takich jak: Arka, Wiara i Światło, Wspólnoty Jerozolimskie, Wspólnota Błogosławieństw, Emmanuel, Chemin Neuf, Chleb Życia i wiele innych. Odnowily one nie tylko oblicze Kościoła we Francji, ale mają już swe komórki organizacyjne w innych krajach europejskich (także w Polsce), przyczyniając się do odnowy oraz pogłębiania lokalnego życia religijnego. We Włoszech - takie wspólnoty, jak Focolari, Comunione e Liberazione, Wspólnota św. Idziego też powstaty z myślą o ponadgranicznym funkcjonowaniu ewangelizacyjnym i działaja $w$ wielu krajach. W Hiszpanii działa aktywnie Droga Neokatechumenalna. W znacznie mniejszym stopniu natomiast wspólnoty takie są obecne na obszarze kultury niemieckojęzycznej; tam dominuje duszpasterstwo tradycyjne, w uzależnieniu i ramach instytucjonalnych. Polska pod tym względem stanowi połączenie tych opcji. W środowiskach wiejskich dominuje bowiem tradycyjny model duszpasterstwa, spełniając efektywnie swoją rolę. W środowisku wielkomiejskim, np. młodzieży akademickiej działają wspólnoty, w których księża promują nowy model duszpasterstwa oparty na dużej wiedzy (teologicznej, psychologicznej i społecznej) oraz cechach charyzmatycznych. Zespół tych cech (charyzmatyczny ekspert) kreuje najskuteczniejszy model autorytetu wśród młodych ludzi. 


\section{Kościół Polski w Europie z perspektywy historycznej}

Kościół w Polsce stanowi organiczną część Kościoła w Europie, co więcej część dość specyficzną. Kościół w Polsce jest w przeważającej mierze łaciński. $\mathrm{Na}$ tradycji zarówno naszego Kościoła, jak i polskiej mentalności w decydujący sposób zaważyły tradycje I Rzeczypospolitej Obojga Narodów oraz problemy związane $z$ życiem pod zaborami, wzmocnione dramatycznymi doświadczeniami minionego wieku, takimi jak II wojna światowa i ciemne pół wieku komunizmu, przepełnionego ateizacyjna indoktrynacja.

Przy całej swej specyfice Kościół w Polsce jest prawdziwym owocem chrześcijaństwa europejskiego, ponieważ w jego kreowaniu brali udzial, oprócz Polaków przedstawiciele innych, obcych nacji odciskając silne piętno na charakterze tej instytucji. Było kilka etapów ingerencji cudzoziemców w tworzenie Kościoła polskiego, prawdziwego „Kościoła pogranicza”. Działalność misyjna na terenie Polski prowadzili na poczatku chrystianizacji prawie wyłącznie cudzoziemcy, św. Jadwiga, Kinga i bł. Jolanta, Wojciech, Brunon z Kwerfurtu, bł. Radzim Gaudenty. Te osoby nierozdzielnie związane $z$ najlepszą i najstarsza tradycja Kościoła w Polsce, wniosły bardzo wiele w budowę polskiej tradycji chrześcijańskiej. Byli także Polscy chrześcijanie, Stanisław ze Szczepanowa, bł. Czesław - byli Polakami, aczkolwiek wykształcenie i formację duchową otrzymali w znacznej mierze za granica.

Religijność instytucjonalną polskiego katolicyzmu modyfikowała więc wielka rzesza cudzoziemców (glównie Niemców, ale także przedstawicieli wielu innych narodowości, choćby Czechów i Ormian), którzy w ciagu stuleci osiedlali się w Polsce, stopniowo wrastając w naszą kulturę. Oni także przynieśli ze sobą wiele $z$ kulturowych i duchowych tradycji krajów swego pochodzenia, które stopniowo stapiały się z miejscowymi, tworząc specyficzną kulturę katolickiej Rzeczypospolitej. Trzeba podkreślić, że wiele tradycji, do których jesteśmy przywiązani i z których jesteśmy dumni, przywędrowalo do nas z innych krajów (choćby ozdabianie drzewka choinki w święto Bożego Narodzenia). Wielki wpływ na polską kulturę religijną (badanie Biblii) oraz jej tożsamość (identyfikacja, bądź szukanie korzeni religijności i dialog z mniejszymi braćmi w wierze) wywierała w ciągu wieków obecność licznej diaspory żydowskiej oraz rozwój ruchu chasydów (jeszcze w XVII w. 80\% światowej populacji Żydów mieszkało na terenie Rzeczypospolitej).

Świadectwem dla polskiej kultury i Kościola w Polsce był czas „potopu szwedzkiego” w połowie XVII w. Przed „potopem” był to Kościół otwarty na dialog z wszelkiego rodzaju myślą europejska, Kościól, którego przedstawiciele 
uczestniczyli w wielkich religijno-kulturowych wydarzeniach i procesach w Europie. Kościół w Polsce był misyjny, wystarczy wspomnieć działalność misji ewangelizacyjnych polskich franciszkanów i dominikanów na Kresach Wschodnich Rzeczpospolitej. Byla to pokojowa misja ewangelizacyjna, w przeciwieństwie np. do misji ewangelizacyjnej Zakonu Najświętszej Marii Panny prowadzonej za pomocą miecza i ognia. Kultura polska rozwijała się na styku lacińskiej i greckiej tradycji chrześcijaństwa, a Polacy potrafili czerpać korzyści z bogactwa obu tradycji. Polska zasłynęła także z tolerancji religijnej w okresie, gdy w Niemczech ciagle tu i ówdzie toczyły się wojny religijne, a Francja jeszcze nie pozbierała się po Nocy św. Bartłomieja, w Polsce, w 1645 r. mialo miejsce słynne Colloquium Charitativum. Natomiast poczawszy od drugiej polowy XVII w. wyraźnie obniża się w Polsce „próg tolerancji” religijnej (w okresie „potopu” i innych zawieruch wojennych szarpiących Rzeczpospolita pojawiło się przekonanie, że innowiercy polskiego pochodzenia mogą być politycznie niepewni, np. ewangelicy mogliby popierać Szwedów, a prawosławni - Rosjan), a Kościół zaczyna się zamykać w sobie w konsekwencji przemian politycznych i społecznych. Kościół po tych doświadczeniach wyraźnie zmniejszył uczestnictwo w życiu kulturowym, a nawet duchowym ówczesnej Europy.

W okresie rozbiorów na przeważającej części polskich ziem nastapiło charakterystyczne utożsamienie Polaka $\mathrm{z}$ wyznaniem katolickim. W znacznej mierze wynikało to z polityki wyznaniowej zaborców, zarówno pruskich jak i rosyjskich. Jedynym wyjątkiem stał się Śląsk Cieszyński, gdzie pod panowaniem katolickich Habsburgów pojawiły się tendencje odwrotne, ponieważ tam Polak był utożsamiany z ewangelikiem. Ta religijna identyfikacja została dodatkowo wzmocniona najpierw w czasie okupacji hitlerowskiej, a następnie reżimu komunistycznego w XX w. Dominował wtedy katolicyzm ściśle związany z ideami patriotycznymi, nastawiony raczej na obronę jakiegoś status quo, a mniej skłonny do odważnego podejmowania nowych pytań i problemów natury społecznej i religijnej. Po wejściu do Unii Europejskiej sytuacja pod względem działania się zmieni. Wprawdzie w Unii też jako naród jesteśmy utożsamiani z katolicyzmem, jednak mamy nowe zadania ewangelizacyjne. Podkreśla je zarówno papież Jan Paweł II, dostrzegają to również czołowi przedstawiciele europejskiej elity politycznej i gospodarczej, tacy jak Jaques Delors, Hanna Gronkiewicz-Waltz, Hors Ganges, czy też sam Robert Schuman, który stwierdzil, że Demokracja albo będzie chrześcijańska, albo jej nie będzie. Demokracja antychrześcijańska jest karykaturq, która skończy się albo tyraniq, albo anarchiq. 


\section{Kościół wobec trudnych wyzwań naszych czasów stojących pod sztandarem zjednoczenia i liberalizmu}

Pośród dzisiejszych wyzwań i zagrożeń na pierwszym miejscu wymieniany bywa współczesny liberalizm, przy czym sprawę komplikuje fakt, że często dochodzi do pomieszania pojęć liberalizmu w dziedzinie polityki, gospodarki i kultury. Kościół coraz bardziej docenia doniosłość i zalety doktryn liberalnych, zarówno w polityce jak i w ekonomii, o tyle liberalizm kulturowy, a przede wszystkim etyczno-wychowawczy jest teraz poważnym wyzwaniem. Niekiedy zdarza się bowiem, że prowadzi do relatywizmu etycznego, a konsekwencja sa trudności w sformułowaniu pytań natury moralnej oraz udzielenia na nie odpowiedzi. Budzi to uzasadnione obawy Kościoła jako wspólnoty, gdyż w imię liberalizmu kulturowego głoszone są tu i ówdzie hasła dopuszczalności aborcji, eutanazji, zrównania $\mathrm{w}$ prawach zwiazków homoseksualnych $\mathrm{z}$ małżeństwami. Stanowi to atrakcyjną pokusę dla kreowanego zróżnicowanego społeczeństwa ponowoczesnego, zwłaszcza, że państwo dostarcza legislacyjnych uzasadnień dla tego typu rozwiazzań.

Są także liczne wyzwania lokalne, wlaściwe dla konkretnych grup kościelnych i poszczególnych krajów. Biorąc pod uwagę skalę zjawiska, największą trudnością jest to, co Alain Besancon określił mianem katastrofy antropologicznej na terenie bylego Związku Sowieckiego. Oczywiście istnieją w tym względzie poważne różnice lokalne, ponieważ zupełnie inaczej wygląda sytuacja w Rosji, a odmiennie na Litwie. Jednak nie zmienia to faktu, że wszędzie tam jest ogrom wyzwań, którym trzeba sprostać, m.in. konflikty międzywyznaniowe (zwłaszcza znana z nieufności, wręcz wrogości postawa Rosyjskiej Cerkwi Prawosławnej wobec postulatu współpracy wszystkich chrześcijan), mało rozbudowana sieć placówek kościelnych, wieloletnie zaniedbania wychowawcze i katechetyczne, niski poziom wykształcenia duchowieństwa szykanowanego przed i po rosyjskiej odwilży.

\section{Mass media na temat integracji religijnej w Europie}

Środki masowego przekazu o rodowodzie katolickim aktywnie włączają się w dyskusje o celowości wstapienia Polski do Unii Europejskiej od momentu zaistnienia problemu. Felietoniści, eksperci, hierarchowie Kościoła nie mówią "nie" dla integracji z Unią Europejska, akcentują jednak zagrożenia wynikające z tego zjednoczenia, nie przemilczając korzyści wyplywających z tego zjednoczenia. Problematyka integracji krajów Europy, także tej w kontekście religijnym i moralnym jest szeroko poruszana $\mathrm{w}$ mass mediach. W prasie, telewizji, 
Internecie zamieszczane są informacje o UE oraz opinie osób wywodzących się ze środowisk opiniotwórczych, zarówno świeckich, jak i kościelnych ${ }^{9}$.

Organizuje się także sympozja i konferencje naukowe, których organizatorzy i uczestnicy próbują odpowiedzieć na wiele nurtujących pytań i watpliwości, a także prognozują o przyszłym wizerunku Europy ${ }^{10}$. Przy czym wizerunek ten dotyczy Unii Europejskiej wraz z Polską i całym jej bagażem kulturowym, moralnym, religijnym i zwyczajowym.

W ramach biurokratycznej struktury Unii Europejskiej powstało Katolickie Centrum Europejskie (Foyer Catholique Européen) w Brukseli. Duszpasterstwem w tym elitarnym centrum jest niemiecki jezuita o. Wolfgang Feler. Zdaniem o. Felbera, dyrektora Centrum, takie organizacje jak FCE, oraz położona w Bruksel ekumeniczna kaplica Zmartwychwstania, maja znaczenie szczególne. Przypominajq one urzędnikom pracujqcym w strukturach Unii Europejskiej, NATO i innych międzynarodowych instytucjach, że obok spraw ekonomicznych, rozporzqdzeń i dyrektyw istnieje ważny świat ducha i Boga - mówi o. Wolfgang Feler. FCE powstało w 1962 r. na życzenie katolickich rodzin pracowników Komisji Europejskiej, glównie z Włoch i Francji. Pracujqcy w instytucjach europejskich urzędnicy nie chcieli przyłqczyć się do duszpasterstwa wspólnot z krajów swego pochodzenia, lecz zapragnęli utworzyć dla siebie rodzaj duszpasterstwa elitarnego - opowiada o. Felber. Na poczatku obejmowało ono głównie katolików z Francji i Włoch, później w latach siedemdziesiąych dołączyli do nich Hiszpanie i Portugalczycy, a kilka lat temu także Polacy pracujący w instytucjach Unii Europejskiej. Nie chcieli oni zamykać się w swoich narodowych gettach, lecz pragnęli tworzyć autentycznq wspólnotę międzynarodowq. Stqqd obok mszy świętych po angielsku, francusku, hiszpańsku, polsku i wlosku, raz W miesiqcu organizowane sq liturgie międzynarodowe - podkreśla dyrektor centrum. Od strony formalnej FCE ma status świeckiego stowarzyszenia, które utrzymuje się jedynie ze skladek członków organizacji i nie korzysta z dotacji, zarówno kościelnych jak i instytucji Unii Europejskiej.

${ }^{9}$ Zob. M. O r ze ch o w s k i: Trzy razy “nie”. „Tygodnik Powszechny”. R. 2002 nr 18 z dn. 05.05 .2002 s. 3.

${ }^{10} \mathrm{~W}$ dn. 12-13.09.2003 odbyla się w Krakowie konferencja nt. Jedna czy dwie Europy? Rola Kościoła katolickiego $w$ procesie integracji europejskie. Organizatorami jest Papieska Akademia Teologiczna, Komisja Episkopatów Unii Europejskiej, Fundacja Konrada Adenauera, Fundacja Roberta Schumana w Luksemburgu, wydawnictwo Wokół Nas. Wystapienia zapowiedzieli m.in. Norma Davies, Danuta Hübner, Helmut Kol, Wladysław Bartoszewski, kard. Paul Poupard, przewodniczący Papieskiej R0ady ds. Kultury, Romano Prodi, przewodniczący Komisji Europejskiej (Integracja po katolicku. „Gazeta Wyborcza” z dn. 12.09.2003 s. 8). 
Oprócz coniedzielnych mszy świętych w różnych językach organizowane sa w centrum nabożeństwa ekumeniczne, spotkania i dyskusje. Członkowie FCE wlączyli się też w debatę nad przygotowywanym przez Konwent Europejski projektem Traktatu konstytucyjnego Unii Europejskiej. W ośrodku prowadzi się katechezę dzieci i młodzieży, jak również przygotowania do pierwszej Komunii świętej i bierzmowania. W ramach działalności duszpasterskiej prowadzonej w Katolickim Centrum Europejskim istnieje dziesięć sekcji językowych, w tym Sekcja Polska. Obejmuje ona przede wszystkim pracowników dwóch polskich placówek dyplomatycznych w Brukseli: ambasady przy Królestwie Belgii i przedstawicielstwa przy Unii Europejskiej, jak również członków delegacji polskiej przy Sztabie Generalnym NATO. Wraz z rozpoczęciem działalności Sekcji 8 grudnia 2000 r. duszpasterstwo wyprzedziło decyzje polityczne. Polska bowiem jest pierwszym krajem, który doczekał się własnej sekcji w Katolickim Centrum Europejskim jeszcze przed wstapieniem do Unii.

Katolickie Centrum Europejskie publikuje sześć razy w roku wielojęzyczny biuletyn „Communitas". Istnieje możliwość jego bezplatnego abonamentu. Wszelkich informacji udziela sekretariat ośrodka: Foyer Catholique Européen, Rue du Cornet/Hoornstraat 51, 1040 Bruxelles/Brussel, Belgique (e-mail: fce@skypro.be). Na stronach internetowych: home.planetinternet.be/ ocipebr/ fce/main.htm i http://www.ocipe.org/foyer-polska.htm można znaleźć aktualny program nabożeństw i spotkań, cotygodniowe rozważania (w języku polskim) do niedzielnej Ewangelii i inne bieżące informacje ${ }^{11}$. Ekumeniczny i prywatny charakter FCE może posłużyć za przykład funkcjonowania organizacji katolickiej ponadnarodowej i ukierunkowanej na dialog z innymi wyznaniami.

\section{Państwo a Kościót - odmienna historia rozwiązania relacji na gruncie państw Europy}

Stopień sekularyzacji społeczeństw europejskich nie zawsze pozostaje w luźnym związku z miejscem, jakie Kościół zajmuje w poszczególnych krajach. Państwa, w których dominuje protestantyzm takie jak Dania, Szwecja, Finlandia, Wielka Brytania, sa jednocześnie państwami wyznaniowymi albo były nimi do niedawna. W Danii Kościołem narodowym jest Kościół ewangelicko-augsburski, a królem może być tylko wierny z tego Kościoła. Państwo utrzymuje Kościół, a parlament uchwala ustawy dotyczące jego organizacji wewnętrznej. Podobnie wyglądało to w Szwecji do 1997 r. i w Finlandii do 2000 r., kiedy przeprowa-

\footnotetext{
${ }^{11}$ Za K. T o m a s i k, P. B i e 1 i ńs k i - e.kai.pl magazyn internetowy katolickiej agencji informacyjnej (http://europa.e.kai.pl//).
} 
dzono rozdział Kościoła od państwa, w wyniku którego Kościól ewangelickoaugsburski utracił status Kościoła państwowego. Również w Wielkiej Brytanii rozpoczęła się poważna dyskusja nad odłączeniem Kościola anglikańskiego od państwa i korony.

Model stosunków państwo-Kościół w krajach protestanckich, obecnie poddawany znacznym modyfikacjom ukształtował się w istocie w okresie reformacji, w opozycji do papiestwa. Wówczas to powstały Kościoły narodowe, co było zgodne z ówczesną protestancką koncepcją miejsca Kościoła w państwie, a także rezultatem wojen religijnych, wstrząsających Europą w XVI i XVII w. Zachodzące obecnie zmiany cywilizacyjne w Europie sprawily, że pochodzący z XVI w. model wzajemnych relacji stał się calkowicie archaiczny i nie przystaje do dzisiejszej rzeczywistości. Dlatego decyzje, jakie podjęto w tej kwestii w Szwecji i Finlandii, wynikają z pewnego ciagu przemian społecznych, a nie bez znaczenia jest fakt, że kraje te należą do najbardziej zsekularyzowanych w Europie.

\section{Religia w Unii Europejskiej - sytuacja Kościoła w Grecji, Wielkiej Brytanii, Niemczech, Francji i Włoszech}

W wielu państwach unijnych zmniejsza się znaczenie tradycyjnych Kościołów w życiu społecznym. W Wielkiej Brytanii już w 1971 r. według sondażu „Times'a” zaledwie 2\% ankietowanych uważało Kościół za bardzo wpływowy czynnik w spoleczeństwie, natomiast pod koniec lat dziewięćdziesiątych niespełna $2 \%$ anglikanów uczestniczyło w niedzielnym nabożeństwie. We Francji zaledwie $10 \%$ katolików udaje się na niedzielną mszę święta, a w ciagu ostatnich pięćdziesięciu lat o połowę zmniejszyła się liczba księży, których było ok. 50 tys. a obecnie jest ich ok. 25 tys. (przy czym trzy czwarte księży ma ponad 65 lat). Nieco lepiej wyglądaja te wskaźniki we Włoszech, ponieważ odsetek praktykujących katolików wynosi ok. $27 \%$, a $86 \%$ obywateli uważa się za osoby religijne. W Irlandii, gdzie katolicy stanowią $91 \%$ społeczeństwa, nadal bardzo wielu ludzi uczestniczy w niedzielnej mszy świętej - ok. 60\%, jednak w porównaniu z 1973 r. nastapił spadek o 30\%. W Niemczech, gdzie do Kościoła katolickiego należy niespełna $27 \mathrm{mln}$ wiernych, zaledwie ok. $4 \%$ regularnie uczestniczy w niedzielnej mszy świętej.

Powyższe przykładowe dane, ilustrują dobitnie rozwijający się proces sekularyzacji w niektórych krajach Unii Europejskiej, czasem traktowanych jako typowo katolickie. Na proces sekularyzacji wpływaja m.in. niekorzystne zjawiska życia społecznego, takie jak rosnąca liczba rozwodów, niski przyrost naturalny, wysoki odsetek aborcji. Z drugiej strony, kraje skandynawskie, gdzie średnio ok. 90\% mieszkańców deklaruje swoją przynależność do Kościoła ewangelicko-augsburskiego, i które są znane z zaniku życiu religijnego, zajmuja 
najwyższe miejsca na listach państw, w których panuje najwyższa wydajność pracy i najmniejsza korupcja (co można przyrównać do stosowania zasad etycznych i religijnych w życiu codziennym).

Niewątpliwie państwa Unii Europejskiej, i całej nie zjednoczonej jeszcze Europy, przechodzą obecnie proces intensywnej sekularyzacji, choć stopień jego zaawansowania różni się w zależności od państwa. Trudno jednak doszukiwać się jego przyczyny w rozwoju Unii Europejskiej. Obydwa zjawiska mają różne korzenie i odmienną historię. Integracja europejska, oprócz sprecyzowanych celów gospodarczych, jest także nastawiona na poszukiwanie jedności i porozumienia, poprzez prowadzenie dialogu i poszanowanie różnorodności kulturowych i światopoglądowych. Jest to postawa bliska chrześcijaństwu, które od wieków wdraża taką ekumeniczną postawę wśród wiernych. Unia Europejska jest u swoich podstaw budowana na zasadach wypływających z Ewangelii (jak choćby solidarność, poszanowanie godności człowieka, równość, subsydiarność). Nie można jednak pozostawić w rękach urzędników z Brukseli decyzji na szczeblu sfery codziennego życia duchowego, które mogłoby być etyczne, jednak nie zawsze religijne ${ }^{12}$.

Większość mieszkańców Europy nie podważy wyjątkowego i znacznego wkładu, jaki ma chrześcijaństwo w osiagnięcia społeczne i kulturowe Starego Kontynentu. Przykazanie miłości, szeroko rozumiane pojęcie godności ludzkiej, koncepcja wolności jednostki, braterstwo i oddanie - to kluczowe idee, który nadały kształt i tożsamość dzisiejszej Europie. Idee te stały się jej desygnatami i pozwoliły na wyzwolenie siły twórczej drzemiącej w mieszkańcach Europy skonsolidowanych w jedna grupę religijną. Przez wiele stuleci chrześcijaństwo było elementem ideowym wpływającym na aktywność intelektualnych sfer kontynentu. Punktem zwrotnym w kreowaniu modelu relacji pomiędzy państwem i Kościolem, była rewolucja francuska, ponieważ w dzisiejszych państwach czlonkowskich Unii Europejskiej można zaobserwować postępujący i nasilający się proces prywatyzacji religii oraz utraty przez Kościoły politycznego i społecznego znaczenia. Nabrał on szczególnego przyspieszenia w ostatnich czterdziestu latach i jest bez wątpienia rezultatem przemian myślowych, jakie najpierw nastapiły w Europie oświeceniowej, a później w wyniku II wojny światowej i światowej rewolucji technologicznej, która zmieniła świat w „globalną wioskę". Nominalnie zdecydowana większość mieszkańców Unii Europejskiej nadal jest dzisiaj chrześcijanami: w Niemczech - ok. $75 \%$ (z czego 32\% to katolicy), we Włoszech - 97\% (w większości katolicy), w Wielkiej Brytanii - ok. 75\% (12\% to katolicy), we Francji - ok. $80 \%$ (w tym ok. $75 \%$ to katolicy). Jednak w rzeczywistości niewielu ze statystycznych wierzących aktywnie uczestniczy w życiu

${ }^{12}$ B. D ' A b o vill e: Europa nie eutanazja. „Gazeta Wyborcza” z dn. 23.11 .2001 s. 16-19. 
swoich Kościołów. Bardzo często dominuje przekonanie, że wiara należy do sfery calkowicie prywatnej i nie powinna być obecna w sferze publicznej. Taka tendencja jest rozpowszechnione zwłaszcza w krajach o tradycji protestanckiej, które biorąc pod uwage wskaźniki w większym stopniu, niż katolickie państwa Unii Europejskiej uległy sekularyzacji. Jednak praktycznie we wszystkich państwach Unii Europejskiej można zauważyć coraz mniejszy udział wiernych w praktykach religijnych, spadek powolań do życia kaplańskiego i zakonnego w Kościele katolickim, a także spadek liczby osób chętnych do podjęcia posługi pastora w Kościolach protestanckich. Zjawiskom tym towarzyszy również postrzeganie Kościoła i głoszonych przezeń zasad, jako jednego z wielu „towarów” w postmodernistycznym hipermarkecie przekonań i idei. Stąd też wielu ludzi przestało uczestniczyć w życiu tradycyjnej wspólnoty religijnej, natomiast zaczęto szukać doświadczenia religijnego na własną rękę, w oparciu o lektury czy spotkania nieformalnych grup religijnych. Sa to ugrupowania o cechach sekt lub swoiste „świeckie” modele interpretujące rzeczywistość (światopoglądy), takie jak ruch New Age, systemy oparte na filozofii wschodu (np. zen, misja czajtani, ruchy krysznaickie, stowarzyszenie Osho Friends, itp. ${ }^{13}$ ), subkultury mlodzieżowe, „kultura LSD” (zasadzająca się na odurzaniu narkotycznym, by otworzyć drzwi umysłu), polityczne i quasi-polityczne ideologie o religijnych funkcjach, zawierające mniejszy ładunek transcendentalnie subiektywnych filozofii, czy wreszcie psychoanalitycznych mądrości życiowych ${ }^{14}$.

Grecja. Jedynym państwem w przeważającym stopniu prawosławnym w Unii Europejskiej jest Grecja i jest to państwo prawosławne w pełnym tego słowa znaczeniu, o czym może nawet świadczyć zapis w konstytucji mówiący, że prawosławne chrześcijaństwo jest religiq dominujqcq w Grecji (art. 3). Kośció1 prawosławny jest de facto Kościolem państwowym. Jest to rozwiazanie zbliżone do modelu skandynawskiego jednak Kościół prawosławny w Grecji, w przeciwieństwie do Kościoła ewangelickiego w państwach północnoeuropejskich, nie unika okazji, aby wplywać na państwo. Stanowisko to stanowi rezultat prawosławnej koncepcji stosunków państwo-Kościól, zgodnie z którą przynależność do określonego narodu wiąże się automatycznie z przynależnością do określonej religii. Religia i Kościół prawosławny odegrał szczególną rolę w historii Grecji wpierając naród w zachowaniu tożsamości narodowej i przetrwania dominacji

${ }^{13}$ Zob. Z. D r o z d o w i c z: Nowe religie orientalne. „Wiedza i Życie” nr 11/1997; W. W i lows ki: Hinduizm. „Wiedza i Życie” nr 1/1996; Z. I g i els k i: Ahmadijja. „Wiedza i Życie” nr 2/1997.

${ }^{14}$ Za P.M. Z u l e h n e r: Religia z wyboru jako dominujaca forma społeczna. W: Socjologia religii. Antologia tekstów. Wybór W. Piwowarski. Kraków 1998 s. 385. 
ottomańskiej. Grecy o tym pamiętaja, a odbiciem tej pamięci są konflikty i incydenty graniczne na grecko-tureckim Cyprze ${ }^{15}$.

Wielka Brytania. Anglikanizm jest w dużej mierze syntezą katolickoprotestancką ze szczególnym uwzględnieniem historii Kościoła w Anglii. Od czasów Henryka VIII Kościół anglikański jest Kościołem narodowym Anglii, a od XVII w. całej Wielkiej Brytanii. Jego głowa jest król, noszący tytuł „obrońcy wiary”, koronowany zawsze przez arcybiskupa Canterbury. Trzeba podkreślić, że nadal utrzymane jest w mocy prawo z 1701 r., zgodnie z którym katolik nie może wstapić na tron brytyjski, nie może też wziąć ślubu z monarchą. Hierarchowie Kościoła są aktywni w życiu politycznym kraju, biskupi reprezentuja Kościół w parlamencie i są członkami Izby Lordów. Swoje nominacje biskupie formalnie otrzymują z rąk premiera, który dokonuje wyboru spośród kandydatur przygotowanych przez radę królewską. Ostatnio jednak Kościól anglikański podjąl debatę $w$ tej sprawie i prawdopodobnie rozpocznie dzialania zmierzające do polożenia kresu tej praktyce. Państwowy charakter Kościoła anglikańskiego przejawia się także w licznych praktykach, takich jak modlitwa na początek obrad parlamentu i rad miejskich, w sądach - składanie przysięgi na Biblię, a w szkolach publicznych - nauka religii finansowana przez hrabstwa oraz modlitwa na początku dnia. Śluby zawierane w kościołach nabieraja automatycznie mocy prawnej. Mimo tak silnego umocowania prawnego w państwie, Kościół anglikański w rzeczywistości nie jest zbyt mocno z nim związany i nie pretenduje do odgrywania istotnej roli społecznej czy tym bardziej politycznej. W istocie stanowi po prostu element brytyjskiej tradycji. W przeciwieństwie do tradycji kontynentalnej nikomu specjalnie nie przeszkadza aktualny status Kościoła w państwie, choć większość Brytyjczyków zdaje sobie sprawę z jego archaiczności ${ }^{16}$.

Niemcy są jedynym państwem Unii Europejskiej, gdzie wiodącą rolę odgrywają dwa największe Kościoły, tj. katolicki i ewangelicko-augsburski. Kościoły te mają porównywalną liczbę wiernych (Kościół katolicki 27 a Kościół ewangelicko-augsburski $28 \mathrm{mln}$ ) są jednocześnie w sposób wyjątkowy, biorąc pod uwage Europę, powiązane z państwem na plaszczyźnie finansowej, instytucjonalnej oraz praktyczno-życiowej. Konstytucja z 1949 r. gwarantuje wolność religijną i świecki charakter państwa, a jednocześnie mówi o nauczaniu religii w szkołach publicznych. Istotnym elementem, wyróżniającym niemiecki model stosunków państwo-Kościól w Unii Europejskiej, jest obowiązkowy podatek kościelny. Wynosi on 9\% miesięcznie od wysokości podatku dochodowego i jest ściagany przez urzędy skarbowe (za wyjątkiem Bawarii), które przekazuja go Kościołom, do których deklarują przynależność opodatkowani obywatele. Prawo

\footnotetext{
${ }^{15}$ Zob. J. P a ł a s i ń s k i: Ostatni mur Europy. „Wprost” z dn. 03.02.2002 s. 94-96.
}

${ }^{16}$ Zob. K. Ka r s k i: Anglikanizm. „Wiedza i Życie” nr 4/1996. 
do tego podatku mają wszystkie Kościoły uznane za stowarzyszenia prawa publicznego. Wynika $z$ tego praktyczna konsekwencja, że przynależność wyznaniowa ma charakter formalno-prawny, a decyzja o nieplaceniu podatku kościelnego oznacza deklarację wystapienia z Kościola. Sytuacja taka sprawia, że Kościoły w Niemczech mają zapewnione stałe finansowanie, co mialo znaczący wpływ na planowanie długofalowej dzialalności charytatywnej, edukacyjnej i socjalnej. W Niemczech powstało wiele kościelnych szkól, przedszkoli, szpitali, ośrodków opieki spolecznej. Państwo dotuje też funkcjonowanie tych instytucji, co $\mathrm{w}$ praktyce spowodowało niemal zmonopolizowanie przez Kościoły całego sektora opieki społecznej i poważny udział w szkolnictwie. Niemałe znaczenie miały tutaj możliwości dostępu do unijnych funduszy promujących tego typu inwestycje o wymiarze społecznym.

Ten wyjątkowy model relacji państwo-Kościól jest wynikiem sytuacji, jaka powstała w Niemczech po zakończeniu II wojny światowej i upadku nazizmu. Kościoły katolicki i ewangelicko-augsburski stały się wówczas jedynymi gwarantami odbudowy w oparciu o idee chrześcijańskie życia publicznego w Niemczech. Stąd powstanie systemu demokratycznego w RFN w dużej mierze było inspirowane wartościami chrześcijańskimi. Czynnik religii i wiary znalazł swoje miejsce i odbicie w życiu publicznym w praktycznej działalności partii chadeckich CDU i CSU.

W poszczególnych państwach niemieckich od XVI w. do I wojny światowej panowal, zbliżony do skandynawskiego, model stosunków państwo-Kościól. Dotyczyło to zarówno Kościoła katolickiego, jak i protestanckiego. Jednak w konstytucji Republiki Weimarskiej zrezygnowano z zapisów o religii państwowej i uznano, że najlepszym rozwiązaniem będzie nadanie Kościołom statusu stowarzyszeń prawa publicznego. Rozwiązanie to panuje do dziś, co oznacza, że państwo zapewnia Kościołom wolność potrzebną do realizacji ich zadań. Wiele konkretnych spraw w tych relacjach reguluja konstytucje poszczególnych landów, dając autonomię w stosunku do rządu federalnego. np. Brandenburgia jest pierwszym landem w Niemczech, w którym władze zamierzają zlikwidować lekcje religii w szkołach zastępując je zajęciami z historii idei i wierzeń religijnych oraz wiedzy o etyce. W Niemczech jest wybór pomiędzy lekcją religii prowadzoną przez duchownych katechetów, a lekcją etyki prowadzoną przez świeckich pedagogów. W Niemczech za takim rozwiązaniem opowiada się $84 \%$ obywateli, natomiast przeciwko lekcjom religii opowiadało się $4 \%$ badanych $^{17}$. W Niemczech u podstaw stosunków państwo-Kościół leży zasada wspólpracy dla dobra wspólnego. Państwo jest niezależne od jakiegokolwiek Kościoła, a Ko-

17 Za: A. Goszczyński: Kompleks Darwina. Czego uczymy się na lekcjach religii. „Wprost” nr 44/2001 z dn. 04.11.2001 s.30. 
ścioly i wspólnoty sa autonomiczne w stosunku od państwa, aczkolwiek obydwie instytucje sa otwarte na wspólprace dla dobra spoleczeństwa. Oznacza to ścisła wspólpracę w obrębie systemu opieki spolecznej i socjalnej państwa. Podobny model relacji państwo - Kościól przyjęto w Austrii. Wschodnie landy Niemiec (dawne NRD) tereny, które też odziedziczyly wielkie spustoszenie z czasów komunistycznej, programowej ateizacji (przed kilku laty dane statystyczne wskazywały, że we wschodnich landach Niemiec tylko 5\% ludności wierzy w jakiekolwiek życie pozagrobowe). Po zjednoczeniu Niemiec ten stan rzeczy wydatnie wpłynął na religijność i pozycję Kościoła w całych Niemczech, a dotyczy to zarówno katolików, jak i protestantów.

Francja. Państwo francuskie od czasów Rewolucji Francuskiej deklaruje całkowitą neutralność światopoglądową, przy czym neutralność ta często oznaczała wrogość wobec religii, a zwłaszcza Kościoła katolickiego. Rewolucja francuska wymierzona w monarchię i Kościól katolicki miała m.in. na celu podporządkowanie go republikańskiemu państwu. Był to ważny moment historyczny i spoleczno-polityczny, który zapoczątkowal radykalny rozdział państwa od Kościoła, utrzymujący się do dnia dzisiejszego. W tym modelu państwo starannie unika wszelkich kontaktów z Kościołami (zwłaszcza z Kościołem katolickim), oraz odwołania się do religii. Świeckość państwa przejawia się tu w istocie wrogością wobec religii. Szczytowym momentem tej wrogości była ustawa z 1905 r. wprowadzająca całkowity rozdział Kościoła od państwa, jednocześnie pozbawiając Kościół katolicki pozycji Kościola oficjalnego, gwarantowanej przez Konkordat napoleoński. Kościół utracił także osobowość prawną. Mimo pewnego złagodzenia interpretacji ustawy z 1905 r., wyraźnie zarysowano ogólny trend w postępowaniu państwa wobec Kościołów. Wyjątkiem była i jest po dzień dzisiejszy sytuacja Kościoła katolickiego i innych kościołów w Alzacji i Lotaryngii, które funkcjonują na podobnych zasadach, jak w Niemczech.

Prawo francuskie zabrania np. nauczania religii w szkołach publicznych (nawet udostępniania do tego celu budynków szkolnych - wyjątkowo, można to uczynić na wyraźne życzenie rodziców i poza godzinami lekcyjnymi dla dzieci w wieku 6-13 lat). Przejawem skrajnej laickości państwa francuskiego jest to, że budynki sakralne nie należą do Kościoła, lecz są wlasnością samorządów, bądź państwa (np. katedry). Prawo zakazuje też oficjalnej obecności przedstawicieli władz publicznych na uroczystościach religijnych.

Ten kategoryczny rozdział państwa od Kościoła w ostatnich latach ulega pewnemu osłabieniu, do czego być może przyczyniła się liczna obecność muzułmanów, silnie manifestujących swoje przekonania religijne. Stąd w ubiegłym roku doszło z inicjatywy rządowej do pierwszych od niepamiętnych czasów rozmów rządu z Episkopatem Francji, gdyż wcześniej rząd utrzymywał oficjalne 
stosunki tylko z Kościołami protestanckimi oraz przedstawicielami gmin żydowskich. Być może zapoczątkowanie stałego dialogu państwo-Kościół wprowadzi nowy klimat wobec religii we Francji, klimat ekumenizmu chrześcijańskiego potrzebny, ze względów politycznych, także wladzom świeckim. Francja obawia się coraz bardziej silnej grupy religii muzulmańskiej, której wyznawcy napływaja $\mathrm{z}$ byłych kolonii francuskich. Tworzą oni silne lobby religijne i kulturowe, zagrażają w ten sposób „rdzennym” Francuzom, nawet pod względem demograficznym.

Włochy. Kościół katolicki nadal zajmuje we Włoszech wyjątkowe miejsce. Wynika to $\mathrm{z}$ jednej strony $\mathrm{z}$ doświadczenia historycznego, gdyż chrześcijaństwo od swojego zarania jest obecne na obszarze terytorialnym i kulturowym wspólczesnych Włoch, oraz z faktu, że Rzym jest sercem Kościola, ściśle związanym z papiestwem. Wojna państwa z Kościołem i papiestwem, jaka miała miejsce w okresie jednoczenia Włoch i później po zdobyciu Rzymu przez wojska republikańskie w 1871 r., gdy papież ogłosil się więźniem Watykanu, zakończyła się podpisaniem Traktatów Laterańskich. Konstytucja włoska z 1947 r. podkreśla, że państwo i Kościół katolicki sa każde we własnym zakresie niezależne i suwerenne. Kościół katolicki nie miał i nie ma statusu Kościoła narodowego, aczkolwiek istnieją silne więzy łączące go z państwem. Wpływ na to miało niewatpliwie powiązanie Chrześcijańskiej Demokracji, rządzącej przez wiele lat w powojennych Włoszech, z Kościołem i Stolicą Apostolską. Kościół jest jednym z istotnych uczestników życia społecznego i nadal cieszy się największym zaufaniem w społeczeństwie włoskim. Wspólpraca państwa z Kościołem w sferze socjalnej jest czymś normalnym. Również nauka religii jest wpisana w program szkół publicznych, a tym samym finansowana przez państwo. Kościól otrzymuje też na swoją działalność społeczną i charytatywną dotacje państwowe. Państwo wyszło również naprzeciw finansowym potrzebom Kościoła, stwarzając możliwość odliczenia przez podatników od dochodu darowizny na rzecz Kościoła, która jednak nie może przekraczać określonej sumy. Ponadto podatnicy moga przeznaczyć $0,08 \%$ podatku dochodowego na określony Kościól, z czego korzysta nieco mniej niż połowa podatników, z których ok. 90\% przekazuje pieniądze na Kościół katolicki.

We Wloszech mamy do czynienia z pokojową symbiozą w stosunkach państwo-Kościół. Podobnie wyglądają te stosunki w Hiszpanii. Na Półwyspie Iberyjskim i we Włoszech dziewiętnastowieczne ruchy liberalne również wymierzone byly w Kościół katolicki i zmierzały do jego oddzielenia od państwa. Powstałe w 1871 r. zjednoczone Włochy kierowały się zasada wolny Kościót $W$ wolnym państwie i w początkowej fazie bardzo aktywnie walczyły o zmniejszenie wpływów Kościoła. Na Półwyspie Iberyjskim Kościół katolicki utracił status Kościoła państwowego w latach siedemdziesiątych XX w. Mimo że w trzech 
katolickich krajach Europy Południowej państwo stalo się całkowicie świeckie, to jednak nie zerwało wszystkich więzi z Kościołem. Włochy, Hiszpania i Portugalia zawarly konkordaty ze Stolicą Apostolską, które reguluja miejsce Kościola $\mathrm{w}$ tych krajach. Państwo, zgodnie $\mathrm{z}$ tymi umowami ma $\mathrm{w}$ pełni świecki charakter, gwarantuje Kościolowi pełną wolność i współpracuje z nim w obszarach wspólnego zainteresowania dla dobra wspólnego. W niektórych opracowaniach ten model relacji państwo-Kościół, obecny oprócz wymienionych wyżej państw także w Belgii, bywa nazywany separacją połowiczną.

\section{Sekularyzacja - wzmocnienie, czy unicestwienie religii w zjednoczonej Europie}

Paradygmat sekularyzacji jest najważniejszym podłożem teoretycznym i analitycznym, w kontekście której nauki społeczne postrzegają relację pomiędzy religia (wraz z jej instytucjonalnym charakterem) a nowoczesnościa. Według José Casanova pojedyncza teoria sekularyzacji w istocie składa się $\mathrm{z}$ trzech niejednolitych i nie powiazanych ze sobą twierdzeń. Pierwsze $z$ nich mówi o oddzieleniu się sfery świeckiej od religijnych instytucji i norm, kolejne podkreśla zanik wierzeń i praktyk religijnych, a ostatnie zwraca uwage na proces marginalizacji religii przez jej przesunięcie do sfery prywatnej ${ }^{18}$.

Kard. Godfried Danneels, prymas Belgii ostrzega, że któregoś dnia zetkniemy się z sekularyzacją, także w Polsce, gdyż jest to nieuniknione. Jest ona bowiem przebudzeniem $\mathrm{w}$ świadomości człowieka przekonania, że wszystko może sam, że nie potrzebuje Boga ${ }^{19}$. Można mieć jednak nadzieję, że będzie to oczyszczające dla naszej wiary. Choć wspólnota wiernych będzie mniej liczna, to pozbędzie się wielu fałszywych bożków. Głównym źródłem sekularyzacji jest rozpowszechnione $\mathrm{w}$ obecnej kulturze poczucie, związane $\mathrm{z}$ dobrobytem, że człowiek może wszystko zrobić o własnych siłach. Sam człowiek, żyjący w poczuciu niczym nie ograniczonego sukcesu, stawia się niejako na miejscu Boga. Choć wielu ludzi na Zachodzie dostrzega ten problem, to jednak trudno im przechodzi przez gardło przyznanie, że są ograniczeni, grzeszni oraz że potrzebuja Bożej pomocy i Jego miłosierdzia.

Czy kraje Europy Środkowej i Wschodniej szybciej ulegną sekularyzacji po wejściu do Unii Europejskiej? Zależy to od wewnętrznej siły religijnych przekonań konkretnych ludzi oraz od siły ich sprzeciwu wobec hedonistycznego i kon-

\footnotetext{
${ }^{18}$ Za: J. C a s a n o va: Deprywatyzacja religii. W: Socjologia religii. Antologia tekstów, dz. cyt., s. 409.

${ }^{19} \mathrm{~W}$ tym kontekście przejawem sekularyzacji była już budowa wierzy Babel, która mimo konsolidacji ludzi zakończyła się porażką.
} 
sumpcyjnego stylu życia w chwili, gdy poprawia się sytuacja gospodarcza kraju. Wszystko zależy od sily ducha (KAI) ${ }^{20}$.

Ludowa religijność, mimo ustaleń II Soboru wskazującego kierunki oczyszczania często byla wręcz likwidowana przez środowisko intelektualne Kościoła katolickiego $^{21}$. Miało to związek $\mathrm{z}$ wyzwaniami czasów i było podyktowane szybko następującymi przemianami społecznymi po II wojnie światowej. Przemiany w typie religijności miały wiele kontekstów, np. we Włoszech odznaczal się podział na bogata, uprzemysłowiona, zlaicyzowaną północ i biedne, rolnicze, stanowiące ostoję tradycji południe kraju. Równowaga pomiędzy tymi dwoma społecznościami chwiała się m.in. z powodu fali emigracji za chlebem Lombardczyków, Sycylijczyków np. do Australii, Argentyny, czy USA osłabiając liczebnie poludnie, ostoję tradycyjnego katolicyzmu. Na procesy emigracyjne nałożył się także proces ruralizacji i agresywnych przemian spoleczno-gospodarczych i kulturowych skutecznie wzmagając zjawisko postępującej sekularyzacji i osłabienia religijności ludowej. Te przemiany wzbudzily zainteresowanie socjologów i teologów oraz obawy władz kościelnych ${ }^{22}$. Wspominam o tej sytuacji przez wzgląd na adekwatne przemiany społeczno-gospodarcze i demograficzne w Polsce. Polska także znajduje się w bardzo trudnej sytuacji gospodarczej, a poglębia ją wyraźny podział na dwie kategorie, tj. Polskę A i Polskę B.

Luckmann jest autorem socjoreligijnej tezy o prywatyzacji religii we współczesnym świecie [Luckmann 1967, 1972a]. Pogląd ten zwraca się przede wszystkim przeciwko szeroko rozpowszechnionej tezie o sekularyzacji. Zwraca się uwagę na fakt, że religia zinstytucjonalizowana jest obecnie coraz powszechniej zastępowana religią o charakterze prywatnym. Religia sprywatyzowana jest obecnie dominującą formą religii we wspólczesnym społeczeństwie - zgodnie z tezą Luckmana. Jest to forma idealna - typ docelowy procesu laicyzacji i deinstytucjonalizacji religii. Religia jest stopniowo pozbawiana ram instytucjonalnych, lub ramy te są bardziej elastyczne. Religia z wyboru ${ }^{23}$ stanowi być może formę przejściową pomiędzy religijnością kształtowaną przez instytucję, a religią i religijnością o charakterze prywatnym.

Zulehner podkreśla tutaj znaczenie i definiowanie religijności i kościelności. Pod pojęciem religijności rozumiemy wszelkiego rodzaju „religię prywatnq",

20 Cyt. za - e.kai.pl magazyn internetowy Katolickiej Agencji Informacyjnej (http://europa.e.kai.pl/) z dn. 29.09.2003.

${ }^{21}$ Zob. M. E 1 i a d e: Historia wierzeń i idei religijnych. T. 3. Warszawa 1995 s. 121-149.

${ }^{22}$ Zob. A. B o n i e ck i: Wroski Kościól szuka drogi. „Tygodnik Powszechny”. R. 2003 nr 28(2818) z dn. 29.06.2003.

${ }^{23}$ Zob. P.M. Z u l e h n e r: Religia z wyboru jako dominujaca forma społeczna, dz. cyt., s. 383. 
która jako specyficzna pojęciowa matryca umożliwia czlowiekowi interpretacjję świata, siebie samego i innych, jego życia codziennego oraz kryzysów, które go spotykajq [Luckmann 1967,1971b]. Kościelność jest również pewnego rodzaju religijnościq subiektywnq, jednakże „uwarunkowanq, ograniczonq i ukształtowanq $w$ wyniku uformowanych uprzednio przez społeczenstwo, zinstytucjonalizowanych systemów językowych, systemów symboli, postaw i działań [Luckmann 1960:133]. Tak więc religijność i kościelność w żadnym wypadku nie wykluczaja się nawzajem. Kościelność jest raczej specyficznq formq religijności, istniejqca obok innych form religijności, nie ukształtowanych przez instytucje (Kościofy)" ${ }^{24}$. Wyraźne określenie w/w zagadnień prowadzi nas do wprowadzenia typologii zachowań religijno-kościelnych mających wielowymiarowa formę, z uwagi na uwzględnianie calego szeregu kryteriów. Uwzględnia ona (1) uczestnictwo ludzi w religii zinstytucjonalizowanej. W zależności od stopnia jego intensywności rozróżniam uczestnictwo pełne, częściowe, jak i całkowity jego brak. Udział jednak musi być wówczas zróżnicowany (2) nie tylko pod względem ilościowym. Zasadniczo na wszystkich płaszczyznach uczestnictwa należy odróżniać aktywnych od konsumentów. Szczególnego znaczenia to zróżnicowanie nabiera $w$ „aktywnym segmencie" Kościoła, a więc fakt istnienia obok aktywnego, pełnego chrześcijanina równiez typu chrześcijanina biernego. Poza tym uwzględnić trzeba (3) instytucjonalny model, według którego kształtowane sq ich działania. $W$ tym celu do dyspozycji Kościoła katolickiego stoja dziś obok modeli tradycyjnych okresu potrydenckiego znacznie starsze modele tzw. „romantyzmu pierwotnego chrześcijaństwa”, a ponadto model II Soboru Watykańskiego oraz wiele innych typów posoborowej kościelności. W rozważaniach istnieje wreszcie (4) konieczność uwzględnienia poza wymiarem jednostki i instytucji również wymiaru rzeczywistości społecznej. To właśnie ten ostatni wymiar najbardziej znaczqco różnicuje bowiem modele religijności instytucjonalnej, bez względu na to czy sq one tradycyjne, przed- czy posoborowe. Zasadniczo możliwe jest istnienie dwóch postaw. Jednq z nich opisać możemy za Glockiem i innymi [Glock, Ringer, Babie 1967] jako zorientowanq na zadowolenie(comfort-oriented): chrześcijaństwo tego typu przynosi przede wszystkim pocieszenie, przystosowanie, pomoc w pokonywaniu kryzysów, usprawiedliwienie zajmowanych pozycji, stabilność i bezpieczeństwo. Model chrześcıjański może mieć też charakter postawy zorientowanej na sprzeciw (challenge-oriented): $w$ tej formie przynosi on konfrontacje, polemiki, impulsy społeczno-krytyczne i impulsy wplywajqce na zmiany społeczne, jak również dynamikę kształtujqcq i przeobrażajqcq życie ${ }^{25}$.

\footnotetext{
${ }^{24}$ Cyt. za - tamże, s. 384.

${ }^{25}$ Cyt., jw., s. 384-385.
} 


\section{Kapłaństwo. Nowa wizja obyczajowej profesjonalizacji posłania}

Przemiany w nastawieniu czlowieka współczesnego wobec skali ważności i podstawowych autorytetów moga posłużyć do stworzenia strategii reakcji Kościoła na te czynniki. Takimi autorytetami są: a) Bóg i Jego ziemscy przedstawiciele; b) starcy i przodkowie, posiadający autorytet ze względu na doświadczenie i tradycję; c) dziedziczni posiadacze władzy ekonomicznej i politycznej; d) przywódcy charyzmatyczni, ze względu na ich osobowość oraz domniemane intuicyjne zdolności; e) biurokratyczno-racjonalne instytucje, reprezentujące obiektywną i wyspecjalizowaną wiedzę ekspertów. R.F. Behrend poprzez badania i ankiety podkreśla, że dokonalo się pewne przesunięcie w dziedzinie ważności autorytetów we współczesnym społeczeństwie. Najwyżej oceniani sa wyspecjalizowani eksperci oraz przywódcy charyzmatyczni. Dopiero później plasuja się autorytety ze wzglẹdu na posiadanie, autorytet religijny, a kończąc na tradycji i wieku ${ }^{26}$. Jest to ważna informacja dla duchownych prowadzących akcje ewangelizacyjne wśród wiernych. Kościól potrzebuje więc świetnie wyszkolonych ekspertów z wielką charyzma.

Bardzo często pada zarzut, że społeczeństwo polskie jest antyklerykalne, zarzut stawiany przez przedstawicieli mediów i świata polityki. Ojciec Maciej Zięba odpowiada, że ludzie po prostu są bardziej krytyczni, a media na całym świecie są mniej religijne niż reszta społeczeństwa. Wskaźniki takie jak uczęszczanie na mszę święta, liczba powołań kapłańskich, czy przyjmowanie sakramentów sa stabilne i bardzo wysokie. Jednak sytuacja ulega pewnej polaryzacji, ponieważ maleje środek, natomiast zwiększa się liczba osób chodzących do kościoła kilka razy w tygodniu i ludzi w ogóle nie chodzących do kościoła. Nowym zjawiskiem jest także pluralizm sposobu wyrażania swojej wiary. Są więc zagorzali słuchacze Radia Maryja, czytelnicy „Arki Noego” w GW ${ }^{27}$, fani zespołu „Arka Noego", czy przedstawiciele wspólnot neokatechumenalnych. Znajduje się wiele osób pomiędzy pewnymi skrajnymi granicami sposobu wyrazu religijnego, a zadaniem Kościoła katolickiego jest docierać do takich ludzi ${ }^{28}$. Stąd coraz częściej duchowni diecezjalni i zakonni stawiają na profesjonalizm. W odpowiedzi na to wyzwanie powstała np. podyplomowa Szkoła Kaznodziejów w Krakowie, stworzona przez Studio Retoryki UJ i Studium Homiletyki na PAT. Szkola powstała m.in. dlatego, że trudno w Kościele o dialog pomiędzy „pasterzem”, a „wiernymi-owieczkami”. Dominuje natomiast nadal retoryka karcącego nie-

\footnotetext{
${ }^{26}$ Por. P.M. Z u l e h n e r, dz. cyt., s. 392-393.

${ }^{27}$ Stała rubryka w "Gazecie Wyborczej” - wyd. sobota/niedziela, dotycząca problematyki Ko ścioła katolickiego i wiary.

${ }^{28}$ Zob. wywiad z o. M. Z i ę b a, pt. Taki Kościół jacy ludzie. „Newsweek” nr 7/2002 z dn. 03.03.2002 s. 87.
} 
grzeczne dzieci rodzica lub niezrozumiały dla wiernych teologiczny żargon. Tak twierdzi Bożena Matuszczyk, ekspert z KUL zajmująca się badaniem języka współczesnych kazań. Uświadamia to brak relacji pomiędzy nadawca - księdzem, a odbiorca - wiernym. W krakowskim studium uczy się księży, ojców i siostry prowadzenia debat, udzielania wywiadów, a nawet wygłaszania toastów okolicznościowych ${ }^{29}$.

Retoryka to nie tylko bezduszna technika, ale cały system filozoficzny. Jedna $z$ jej zasad podkreśla, że odbiorca jest inteligentny i wymagający. Wymogiem retoryki jest także wiarygodność. Wśród wolnego rynku idei zwyciężą więc ci, którzy przeżywają i wierzą w to co mówią. A wierni przestają przyswajać sobie utrzymywane w teologicznym żargonie kazania i listy pasterskie. Skuteczną nowością więc, biorąc pod uwagę frekwencję bylo wprowadzenie kazań dialogowych, podczas których dwaj kaznodzieje dyskutują na ambonie. Kazania tego typu zapoczątkowali w Polsce dominikanie o. Michał Zioło i Maciej Zięba. Innym rodzajem ewangelizacji są kazania spacerowe, które w Rzeszowie i Sandomierzu prowadził o. Konopka, ${ }^{30}$ przedstawiając w ciagu 3-4 minut problem. Kaznodzieja ma na celu zaintrygowanie i skłonienie do przemyślenia problematycznej kwestii, a nie podanie gotowych odpowiedzi.

Przygotowanie Polaków do wejścia w struktury Unii Europejskiej to jedno z najpoważniejszych wyzwań, które stoi przed Kościolem katolickim. Inne równie trudne zadanie to pomoc duchownych w odnalezieniu się wiernym w coraz trudniejszych czasach. Bp Tadeusz Pieronek ustosunkowując się do tych zadań twierdzi, że albo znajdziemy się w Unii, albo na marginesie Europy. Mimo, iż sama kwestia zjednoczenia nie jest prawdziwą kwestią religijną, to dzieli ona katolików Stąd zadaniem kapłanów jest rzetelnie informować wiernych o korzyściach i zagrożeniach czekających na Polaków od maja 2004 roku. Kapłani winni wskazywać także droge w nowej rzeczywistości, jak czyni to abp Damian Zimoń, ekspert w dziedzinie walki z dysfunkcyjną plagą społeczną dzisiejszej Polski, tj. bezrobociem. Abp Zimoń nawiązał współpracę z prezesem Biznes Centem Club Markiem Goliszewskim odnośnie realnego tworzenia nowych miejsc pracy poprzez zmniejszenie obciążeń fiskalnych i ubezpieczeniowych spoczywających na pracodawcy. Abp Damian Zimoń dostrzega problem jasno, by stworzyć nowe miejsca pracy to musi się wszystkim opłacić. Za deklaracjami idzie także współpraca struktur edukacyjnych, w parafiach na terenie diecezji katowickiej powstały np. ośrodki organizujące kursy zawodowe dla osób zwalnianych z pracy.

${ }^{29}$ Zob. D. H o 1 o w n i a: Polski Kościót. Kazać, ale inaczej. „Newsweek” nr 7/2002 z dn. $03.03 .2002 \mathrm{~s} .88 \mathrm{nn}$.

${ }^{30}$ Zob. j.w., s. 89 . 
Naturalną konsekwencja katastrofalnego bezrobocia w Polsce jest pogłębiająca się bieda. Głód przestal być zjawiskiem dotykającym biedne kraje tzw. III świata, jest coraz bardziej dostrzegalny w Polsce. Walką z biedą i glodem, oraz skutkami katastrofalnych powodzi i susz zajęła się Caritas Polska. Działalność charytatywna Kościoła wypływa z głoszonych zasad wiary i jest w Polsce zakrojona na szeroką skalę. Dzialalność ta obejmuje praktycznie osoby z wielu zagrożonych grup spolecznych, zagrożonych patologią społeczną lub po prostu pozostawionych na marginesie życia społecznego ${ }^{31}$. Roczna pomoc udzielana potrzebującym w kraju i poza jego granicami waha się w granicach $200 \mathrm{mln}$ złotych ${ }^{32}$. Powstaja jadłodajnie dla osób bezdomnych i słabo sytuowanych materialnie, dla których często posiłek ten jest jedynym ciepłym daniem w ciagu dnia. W obrębie takiej działalności charytatywnej nawiązuje się także dialog międzywyznaniowy, np. w Białymstoku kompleksowa opieka nad osobami bezdomnymi jest finansowana wspólnie przez Caritas i prawosławny Ośrodek.

Kościól katolicki w Polsce kładzie coraz większy nacisk na misję ewangelizacyjną w nowych warunkach liberalnego, ekscentrycznego spoleczeństwa informatycznego. Lekcje religii $\mathrm{w}$ szkołach nie wzbudzaja dzisiaj zbyt wielkich emocji, jednak bywają często mało efektywne ${ }^{33}$. Wielu księży i katechetów postuluje zmiany, jednym z nich jest o. Jan Góra, dominikanin przyciagający młodzież nowatorską formą katechezy. O. Jan Góra dostrzega potrzebę uwzględnienia nowej percepcji i wrażliwości współczesnych ludzi na obrazy, symbole przekazywane w tempie teledysków z MTV. Przekaz Ewangelii musi docierać do dzisiejszej młodzieży wręcz na poziomie podprogowym. O. Jan Góra realizuje projekt modlitewnych spotkań w Lednicy, gdzie powstała Brama III Tysiąclecia - konstrukcja w kształcie ryby, pierwszego symbolu chrześcijaństwa. Katecheci korzystają też z możliwości przekazu, jakie dają mass media w przekazywaniu przesłania chrześcijańskiego. Jako odzew na to zapotrzebowanie powstała Telewizja Puls kierowana przez franciszkanina o. Jana Suchaka, jest to nowa ambona Kościoła podobnie jak radio i internet. W grudniu 2001 r. powstal internetowy serwis informacyjny e.kai.pl stworzony przez Marcina Przeciszewskiego szefa Katolickiej Agencji Informacyjnej.

${ }^{31}$ Działalność charytatywna zakonów w Polsce. Przedszkola i ochronki - 392; świetlice i ośrodki wychowawcze - 78; szkoły i uczelnie - 169; bursy - 67; domy samotnej matki - 29; apteki - 10; domy dziecka - 55; placówki dla osób upośledzonych i starszych - 261; ośrodki dla uzależnionych - 7; hospicja - 7; przychodnie - 12; szpitale - 6; schroniska - 19; kuchnie dla ubogich 46, za: M. Kar n owsk i, S. H oł own i a: Uzdrowić Kościół. „Newsweek” z dn. 03.03.2002 s.86.

${ }^{32}$ Por. tamże, s.83-86.

${ }^{33}$ Zob. A. G o s z c z y ń s k i: Kompleks Darwina, art. cyt., s.28-30. 
Zapleczem intelektualnym środowiska katolickiego tworzy Katolicki Uniwersytet Lubelski. Znaczący w kraju ośrodek intelektualny kształci kilkanaście tysięcy studentów, tworzy także ośrodki zamiejscowe w Tomaszowie Lubelskim i Stalowej Woli. Ks. Andrzej Szostek wystapil z taka inicjatywą, myśląc o młodych zdolnych osobach, które nie mogly pozwolić sobie na kształcenie w dużych i drogich ośrodkach akademickich ${ }^{34}$. Po zakończeniu przedostatniej pielgrzymki papieża Jana Pawla II do Polski pozostały fundusze, które organizatorzy pielgrzymki przeznaczyli na pomoc potrzebującym. Powołano do życia fundację „Dzieło Nowego Tysiąclecia”, której głównym celem jest wspieranie dzieci ze środowisk dotkniętych biedą. Pomocą objęto ok. 1000 dzieci stwarzając im możliwość zdobycia wykształcenia, a tym samym zwiększając ich szanse w przyszłości na znalezienie zatrudnienia ${ }^{35}$.

Powstają także stowarzyszenia i organizacje o rodowodzie katolickim, które postawily sobie za główny cel tworzenie siły społecznej ugrupowań chrześcijańskich w przyszłej Europie. Forum Świętego Wojciecha zostało powołane w polowie 2002 r. przez ruchy, organizacje i stowarzyszenia katolickie bądź chrześcijańskie pragnące razem pracować nad obecnością głosu polskiego chrześcijaństwa w jednoczącej się Europie. Forum jest platformą spotkań i współpracy poszczególnych ruchów. Prace Forum koncentrują się na spotkaniach eksperckich, na których są omawiane ważne problemy europejskiej przyszłości, w duchu papieskiego nauczania nt. budowy europejskiej jedności, czy formułowania kierunków współpracy pomiędzy ugrupowaniami. Forum prowadzi również działania medialne służące szerzeniu informacji i refleksji nad obecnością Kościola w nowej rzeczywistości europejskiej. Forum Świętego Wojciecha było pomysłodawcą i głównym organizatorem Spotkania Ruchów i Stowarzyszeń Katolickich - IV Zjazdu Gnieźnieńskiego w marcu 2003 r., w którym uczestniczyli przedstawiciele blisko setki ugrupowań i ruchów chrześcijańskich z całej Polski. Forum pracuje pod stałą opieką ks. abp. Henryka Muszyńskiego i w bliskiej wspótpracy z ks. prymasem Józefem Glempem.

\section{Religia a wolny rynek. Marketing religijny}

Kościół w społeczeństwie Zachodnim utracił swoje tajemnicze i intrygujące znaczenie $\mathrm{w}$ zakresie formowania sposobu myślenia i thumaczenia różnych sfer życia codziennego. Tworzy to konfliktowe sytuacje pomiędzy kościelnymi, a

\footnotetext{
${ }^{34}$ Por. M. K a r n o w s k i: Pasterze dusz i rozumu. „Newsweek” z dn. 23.12.2001 s. 46-49.

${ }^{35}$ Zob. także - Rozmowa z ks. Sławomirem Kokorzyckim. Filozofia biedy. "Gazeta Wyborcza” z dn. 14.06.2002 s. 7 .
} 
spolecznymi (świeckimi) systemami wartości i wzorców zachowań. Kościół stał się jednq z instytucji współzawodniczqcych na rynku dóbr symbolicznych ${ }^{36}$.

R. Willson wskazuje, że na współczesną rzeczywistość religijności składa się to, czego sobie życzą wierni, o wiele rzadziej zaś to, czego oczekują od nich Kościoły [Willson 1966: r. I]. W takim ujęciu sytuacja religii i Kościola w nowoczesnym spoleczeństwie wskazuje na zadziwiającą i szeroką swobodę, jaką chcą mieć i mają wierni wobec własnych instytucjonalnych Kościołów. Zaistnialy nowe możliwości wyboru $w$ ofercie Kościołów, np. w wypełnieniu pustki duchowej swoich wiernych-klientów. Stanowi to o nowym rozdziale w dziejach Kościoła i procesu indywidualizacji religijności ${ }^{37}$.

Kapłani z krajów Europy Zachodniej i USA już od wielu lat korzystają z pomocy profesjonalistów $\mathrm{z}$ dziedziny marketingu, przeprowadzając akcje promocyjne religii. Duchowni z Wielkiej Brytanii prowadzą zakrojoną na szeroka skalę kampanię promująca uczestnictwo wiernych $\mathrm{w}$ niedzielnych nabożeństwach. Spece od reklamy opracowali całą aurę towarzyszącą i wzmagającą zainteresowanie „starych” i „nowych” wiernych Kościolem i uczestnictwem w niedzielnych nabożeństwach. W kościołach anglikańskich wierni byli bombardowani sloganami reklamowymi przed wejściem do świątyń. Konsultanci od marketingu sugerowali, by zrezygnować z odczytywania fragmentów Biblii, zwłaszcza apokaliptycznych i podkreślających kruchość człowieka na rzecz radosnego śpiewu psalmów, czy występów chórów gospels. Kazania mają być ciekawe i często kontrowersyjne, by przyciagać do świątyń wiernych, wiernych karmionych bezustannie ekshibicjonizmem telewizyjnym programów typu reality show. Kościól ma być swoistą instytucja psychoterapeutyczną dla trzydziesto i czterdziestolatków ustabilizowanych społecznie i materialnie, ale często cierpiących na wewnętrzna pustkę. Spece od reklamy sugerują, by ze ścian kościołów zdjąć rzeźby i obrazy przedstawiające cierpienie ukrzyżowanego Chrystusa czy piety, ponieważ wizja bólu i śmierci nie sprzyja tej duchowej terapii. W/w grupa wiernych chciałaby raczej zapomnieć niż pamiętać o śmierci, odsuwając od siebie myśl, że vanitas vanitatum et omnia vanitas. Takie podejście jest niezgodne $\mathrm{z}$ obecnie panującą konsumpcyjną filozofią życia, która ma poparcie społeczne $\mathrm{z}$ uwagi na napędzanie koniunktury.

Kościół ma stać się instytucją bliższą dla wiernych parafian, ma tworzyć prawdziwą rodzinę duchową. Na ten wizerunek wpływają szczególy, np. w kościołach ewangelickich prawie normą stało się żegnanie przez pastorów wszyst-

\footnotetext{
${ }^{36}$ Cyt. za: J. M a r i a ń s k i: Kościót w spoleczeństwie przemysłowym. Warszawa 1983 s. 251.
${ }^{37}$ Zob. P.M. Z u l e h n e r: Religia $z$ wyboru jako dominujaca forma społeczna, dz. cyt., s. 392 i nn.
} 
kich wiernych po nabożeństwie. W Polsce w niewielkich wiejskich parafiach też jest już praktykowany ten zwyczaj, konsolidując takimi małymi gestami społeczność lokalną, parafialna.

Zauważa się popyt na markę, jaką jest religia, tworząc m.in. zaplecze wizualne i skojarzeniowe. Tworzy się $n p$. t-shirty $z$ atrakcyjnymi napisami, prowokacyjnymi, ale także deklaracyjnymi. Ten styl trafia na podatny grunt zaangażowanej mlodzieży, skupionej m.in. we wspólnotach neokatehumenalnych. W Polsce na pomysł wyprodukowania koszulek w tym stylu wpadł Grzegorz Górny, jeden z twórców wydawnictwa i pisma „Fronda”. Najpopularniejszy z t-shirtów przedstawia długonoga kobietę, a obok niej napis: Dziewczyny czekajq na twojq modlitwę $24 h$, przez całq dobę. Na innym widać obejmującą się parę i napis w języku angielskim: Żadnego seksu bez małżenstwa i Chrystusa. Na stronach internetowych „Frondy” można zobaczyć postać Batmana, który zapytany, co jest jego siła, odpowiada: Ten facet $\mathrm{i}$ pokazuje medalik $\mathrm{z}$ Jezusem $^{38}$.

Polskie środowisko katolickie skorzystało także z nośnika wiary, jakim może być i jest muzyka. W Polsce coraz popularniejsza staje się muzyka chrześcijańska, rozgłośnie radiowe tworzą nawet listy przebojów tego nowego gatunku muzyki. Wytwórnie fonograficzne mogłyby zainwestować w promocję chrześcijańskiej muzyki rozrywkowej. Spełniłyby wówczas jedno z zaleceń agencji reklamowej. A że taka muzyka podoba się, można się przekonać obserwujac sukcesy Arki Noego (stworzonej przez Roberta Friedricha, bylego muzyka heavymetalowej grupy Acid Drinkers). W tym kierunku tworzy coraz więcej artystów, m.in. Darek Malejonek z Houk czy Tomasz Budzyński, kiedyś lider punkrockowej Armii. W Europie Zachodniej i USA moda na taką misję ewangelizacyjna już miała miejsce, a niektóre jej odsłony, takie jak wystawienie musicalu „Hair” stworzyło kultowy (popkulturowy) wizerunek wartości chrześcijańskich połączonych $\mathrm{z}$ pacyfizmem (realia wojny w Wietnamie), subkulturą hipisów, poszukiwaniem własnej drogi duchowej i muzyką.

W Polsce także dostrzegalny jest ten ogólnoświatowy trend marketingowy Kościoła, wiary, sensu życia i nadziei. Pracownicy firmy reklamowej ze Szczecina umieścili na tramwaju fotografie Jana Pawła II i hasła: Ludzie! Przebaczcie sobie; Swięto młodych trwa bez końca. Na sugestie, że organizatorzy kampanii zniżaja autorytet Ojca Świętego do poziomu reklamy papierosów, czy gumy do żucia duchowni odpowiadaja, że przede wszystkim chodzi o przesłanie. Przesłanie zgodnie $\mathrm{z}$ założeniem głoszenia misyjnego musi trafić do największej rzeszy

${ }^{38}$ Cyt. za: M. W o d n i a k: Keklama jest sposobem zdobywania nowych wiernych. „Kulisy” nr 35 (2003) s. 12 . 
ludzi, ponieważ masowość jest ważnym elementem naszej nowej rzeczywistości spolecznej.

Wiele periodyków o rodowodzie chrześcijańskim, np. magazyn „Odnowa i Chrześcijaństwo”, czy „Tygodnik Powszechny” dostrzegaja swoisty popyt na odnowę duchowa, poszukiwanie nadziei i sensu życia. Człowiek potrzebuje w tych poszukiwaniach dobrego przewodnika, profesjonalnego nauczyciela, określanego coraz częściej jako guru. Wśród osób oferujących łatwą i prostą ścieżkę do tego celu jest wielu oszustów, szarlatanów i naciagaczy bazujących na modzie $^{39}$ i wykorzystujących ludzkie nadzieje i pragnienia dla własnych korzyści.

Na podstawie sygnałów ze strony wiernych i kapłanów można wysnuć wniosek, że religia może i powinna być reklamowana, by zdobywać w ten sposób nowych wiernych i budować lojalność wcześniejszych wyznawców. Reklamy telewizyjne, spoty telewizyjne i radiowe, billboardy, czy promocja face to face budują wizerunek marki, którą może być i jest Kościół katolicki w Polsce. Kampania reklamowa instytucji kościelnych stanowi też formę działań informacyjnych, ponieważ billboardy w okresie przedświątecznym informowały nas o zakrojonej na szeroką skalę akcji „Wigilijne Dzieło Pomocy Dzieciom” organizowanej przez Caritas. Diecezjalny Caritas w Poznaniu organizuje bezpośrednią zbiórkę żywności na rynku jeżyckim, by zaopatrzyć jadłodajnie dla osób bezdomnych i glodnych.

W Mikołowie Kamionce staną billboard z reklamą kościoła, typowo informacyjny, umieszczony przy ruchliwej trasie Katowice - Wisła. Proboszcz miejscowej parafii św. Urbana twierdzi, ze reklama przynosi efekt w postaci wielu „obcych wiernych” na niedzielnych nabożeństwach. Proboszcz mówi, że kościól nie ma wysokiej wieży stanowiącej drogowskaz i reklamę świątyni dla wiernych, więc billboard skuteczniej spełni tę rolę. Reklamują się także jezuici z warszawskiego klasztoru św. Andrzeja Boboli. Jeden z kleryków ułożył hasło „Wygrywamy białymi" umieszczając je pod zdjęciem zakonnika siedzącego przy szachownicy ${ }^{40}$.

Częstym zjawiskiem jest organizacja przez kościoły lub pod ich patronatem wyjazdów-pielgrzymek w miejsca szczególnego kultu, na obchody „Dni Młodzieży", spotkania modlitewne, itp. Pielgrzymki-wycieczki są atrakcyjne dla uczestników z kilku powodów, m.in. są wyprawą duchową, forma rekreacji, są atrakcyjne cenowo (biorą w nich udział emeryci, renciści i młodzież szkolna, tj.

\footnotetext{
${ }^{39}$ Od dłuższego już czasu występuje moda związana z zewnętrznym manifestowaniem swojej wiary. Gwiazdy sportu, np. znani bokserzy zostaja muzułmanami, wielu piosenkarzy, np. Leonard Cohen, czy Swing manifestują zaangażowanie w system religijno-filozoficzny buddyzmu.

${ }^{40}$ Cyt. za: M. Wodniak, dz. cyt., s. 12.
} 
grupy o przeciętnych i niskich dochodach), a także z uwagi na organizatora Kościól uczestnicy nie muszą obawiać się nieuczciwych przewoźników i biur podróży. Ten ostatni argument nie jest bez znaczenia, jeśli zwrócimy uwagę na mnożące się informacje o plajtach wielkich i malych firm turystycznych oraz klientach tychże firm traktowanych jak zakładnicy przez wlaścicieli hoteli i campingów w zagranicznych kurortach.

\section{Podsumowanie. Legislacyjna wizja Kościoła przyszłości}

Na początku należałoby zadać sobie zasadnicze pytanie, czy aspekt życia religijnego i kościelnego danej społeczności można poddać zabiegom takim jak prognozowanie lub przewidywanie? Janusz Mariański uważa, że z socjologicznego punktu widzenia jest możliwe podjęcie zagadnienia, jak członkowie społeczenstwa widzq szanse religii i Kościoła w przyszłości? Czy Kościół w przyszłości utrzyma swój status quo, czy może zyska lub straci na znaczeniu społecznym? Czy w ogóle będzie istniał, czy przeminie? ${ }^{41}$.

Należałoby podkreślić, że zasadą budowania integracji europejskiej jest droga kompromisów oraz zrozumienia dobra wspólnego. Wszyscy uczestnicy tego przedsięwzięcia oddają ważną dla siebie część autonomii i partykularnych interesów na rzecz interesu wspólnego ${ }^{42}$. Istotnym elementem wizji Kościoła przyszłości jest jego status prawny.

Trwaja intensywne prace Konwentu nad przygotowaniem projektu przyszłego Traktatu Konstytucyjnego Unii Europejskiej. Jednym z postulatów, jaki przedłożyły jego członkom Kościoły, jest zachowanie statusu prawnego Kościołów w Unii Europejskiej zgodnie z prawem poszczególnych państw członkowskich. Oznacza to wniosek o włączenie do treści Traktatu Konstytucyjnego tak zwanej „klauzuli o Kościołach”, uchwalonej podczas Rady Europejskiej w Amsterdamie w $1997 \mathrm{roku}^{43}$. Zapis z amsterdamskiego spotkania ma gwarantować Kościołom w Unii Europejskiej autonomiczny charakter względem państwa, także ich dotychczasowy status, który w wypadku niektórych państw stanowi rezultat kompromisu, do którego dochodzono przez dziesięciolecia w poszczególnych krajach. Przebieg obrad Konwentu daje podstawy, aby mieć nadzieję, iż postulat zachowania przez Kościoły swojego dotychczasowego statusu zostanie uwzględniony w przyszlym fundamentalnym dokumencie Unii, tym bardziej, że 28 lutego członkowie Konwentu przyjęli poprawkę do art. 1 par. 2 projektu

${ }^{41}$ Cyt. za: J. M a r i a ń s k i: Kościół w społeczeństwie przemysłowym. Warszawa 1983 s. 235.

${ }^{42}$ Por. M. Or ze c h o w s k i: Trzy razy "nie", dz. cyt., s. 3.

${ }^{43}$ Unia przestrzega statusu, jakim ciesza sie Kościoly oraz stowarzyszenia i wspólnoty religijne $w$ państwach członkowskich odpowiednio do ich przepisów prawnych, tak, aby nie zostały one naruszone. 
Traktatu, który brzmi: Unia powinna respektować tożsamości narodowe państw członkowskich, jak również ich politycznq i konstytucyjnq strukturę, włqczajqc regionalne i lokalne samorzqdy, ich wybór dotyczqcy języka oraz statusu prawnego Kościołów i wspólnot religijnych. Tym samym Unia zrzeka się pretensji do ingerowania w wewnętrzne ustawodawstwo państw czlonkowskich odnoszące się do prawa wyznaniowego i uznaje aktualny stan rzeczy, a więc także różnorodność rozwiązań w tej materii. Projekt Traktatu może dawać nadzieje, że ludzie pracujący nad kształtem przyszlej Europy nie chcą uniformizować wszystkich wymiarów życia i poddawać ich jednemu prawu. Przyjęcie w krajach unijnych zunifikowanych i jednolitych rozwiązań dobrze sprawdza się w dziedzinie gospodarki, finansów czy sądownictwa, to wcale nie musi dobrze funkcjonować np. w sferze religii czy kultury. Dlatego Unia Europejska stawia na różnorodność i autonomiczność Kościołów w poszczególnych krajach.

Religia zinstytucjonalizowana w formy Kościoła odgrywała w Europie bardzo istotną rolę, jednak $\mathrm{w}$ ostatnich dwustu latach ulega ona zmniejszeniu i ograniczeniu. Dotyczy to wszystkich Kościołów, zwlaszcza protestanckich, w mniejszym stopniu Kościoła katolickiego i prawosławnego w Grecji. Widać wyraźnie, że w zależności od państwa pozycja Kościoła i jego znaczenie w spoleczeństwie jest różne. Stąd dobrym sygnałem jest to, że Unia nie zamierza ingerować w status Kościołów w państwach czlonkowskich i chce zachować różnorodność istniejących rozwiązań w stosunkach państwo-Kościól, które odzwierciedlają historyczne uwarunkowania i poszczególne tradycje narodowe. Z punktu widzenia polityki i obecnej fali terroryzmu, wiązanego w sposób automatyczny $\mathrm{z}$ religią muzułmańską (wzrastająca obecność i aktywność, także fundamentalistyczna muzułmanów w państwach Unii Europejskiej) będzie prowadziła do rewizji wagi religii w życiu społecznym, co prawdopodobnie stworzy dla Kościołów chrześcijańskich okazję do aktywnego wspierania tendencji zjednoczeniowych i unifikacyjnych w Europie.

Dziś, gdy w wielu krajach Europy odczuwany jest niedostatek powołań kapłańskich i zakonnych, polscy księża, podobnie jak siostry zakonne, mogliby wiele pomóc w duszpasterstwie w innych krajach. Wymaga to jednak umiejętności wejścia w kulturę tych krajów, a więc także w ich historię, literaturę, w specyfikę tamtejszej tradycji chrześcijańskiej. Stanowi to poważne wyzwanie, bo aby się czegoś nauczyć, trzeba umieć słuchać. Podobnie wiele trzeba się nauczyć, aby móc razem pracować w ramach takich inicjatyw, jak CCEE (Rada Konferencji Episkopatów Europy) czy COMECE (Komisja Episkopatów Wspólnoty Europejskiej).

Ponadto wydaje się, że w ostatnich kilku latach można zauważyć nowe zjawisko, iż politycy zaczynają doceniać wagę religii, zdając sobie sprawę z wła- 
snej bezradności w rozwiązywaniu narastających problemów spolecznych. Przyszłość Kościołów w Unii Europejskiej jest zatem otwarta, a rola, jaką mają do odegrania, nie jest jeszcze w pełni sprecyzowana i zależy w dużej mierze od nich samych. 